

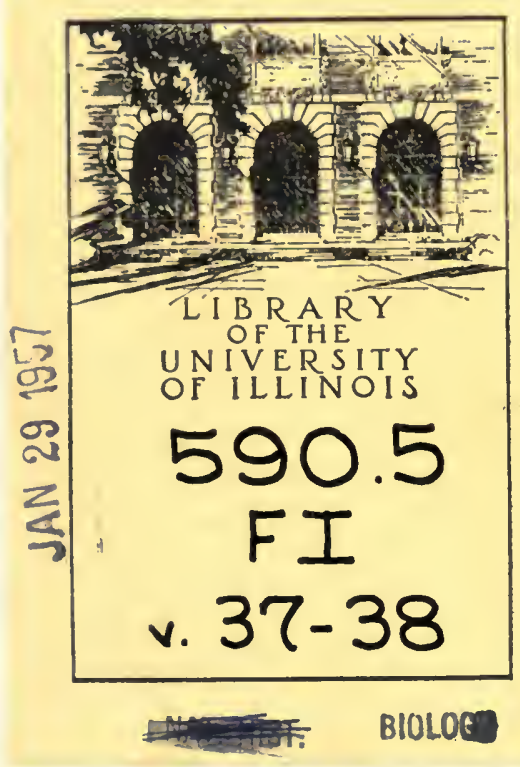


The person charging this material is responsible for its return on or before the Latest Date stamped below.

Theft, mutilation and underlining of books are reasons for disclplinary action and may result In dismissal from the University.

UNIVERSITY OF ILLINOIS LIBRARY AT URBANA.CHAMPAIGN

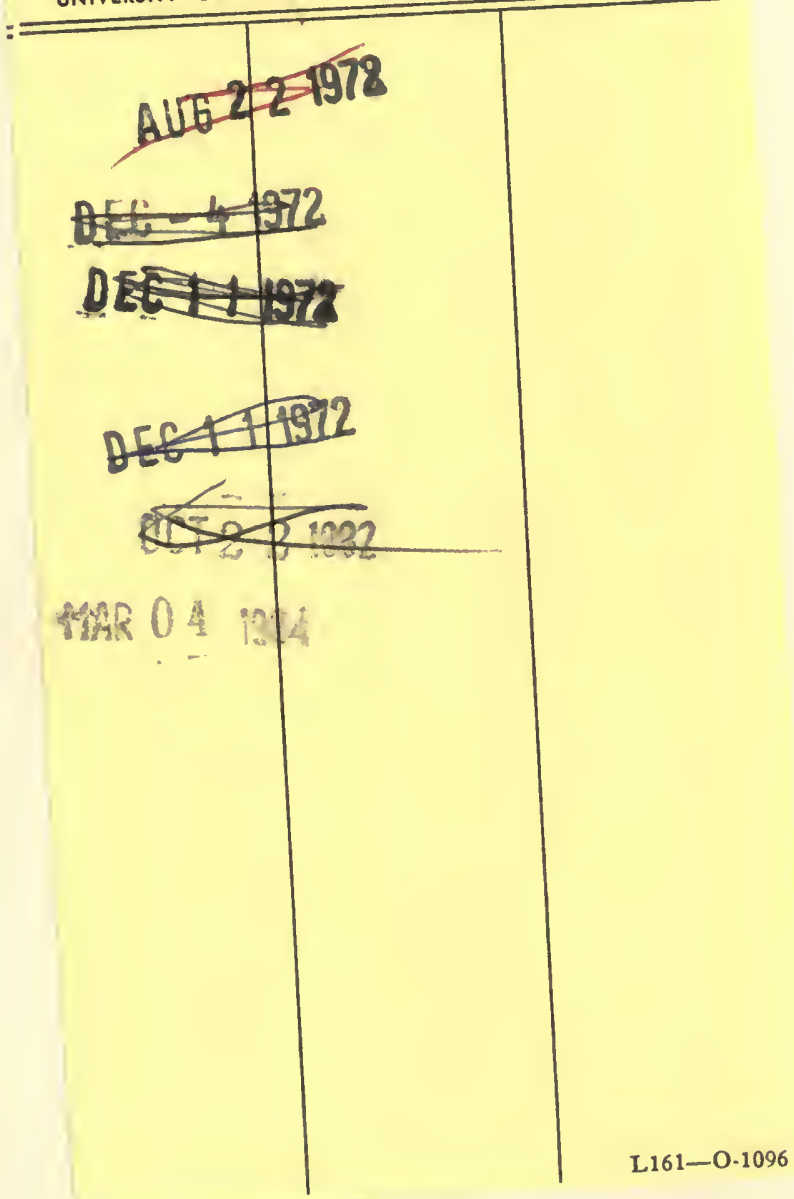







\title{
Geographical Origins and Dispersions of Termite Genera
}

\author{
Alfred E. Emerson ${ }^{1}$ \\ Research Associate, Division of Insects
}

\section{ACKNOWLEDGMENTS}

This paper has been written in honor of Dr. Karl Patterson Schmidt because of our long, close, personal friendship, our mutual interest in zoogeography, taxonomy, ecology, and evolution, and also because of the numerous collections of termites made by Dr. Schmidt during his many zoological expeditions to various parts of the world. We have long been associated in our professional work at the American Museum of Natural History, Chicago Natural History Museum, and the University of Chicago. We have collected together in the field, and we collaborated in writing a book (Allee, et al. 1949). In 1916, near Ithaca, New York, Dr. Schmidt showed me the first living termites I had ever seen, some years before I started to specialize on the order in British Guiana under the leadership of Dr. William Beebe.

Financial assistance in gathering the information contained in this summary treatment has been generously given by the Dr. Wallace C. and Clara A. Abbott Memorial Fund of the University of Chicago, the New York Zoological Society, the John Simon Guggenheim Foundation, and the Belgian American Educational Foundation. I have also received generous collaboration from the leading students of termites of the world during the twentieth century and have exchanged specimens with many natural history museums. Such a study as this could not have been accomplished without international co-operation of many scientists and scientific institutions. I am greatly indebted to my wife, Eleanor Fish Emerson, for assistance in the preparation of the manuscript.

${ }^{1}$ Professor, Department of Zoology, University of Chicago. 


\section{INTRODUCTION}

As the result of the catalogue of the termites of the world by Snyder (1949) and the phylogenetic studies by Holmgren (1911, 1912), Hare (1937), and Ahmad (1950), termite systematics has matured to the point where zoogeographical interpretations rest upon a substantial foundation. Many new genera and species doubtless await discovery, and some changes in the postulated relationships may be expected. Ahmad (1950) verified far more of the conclusions drawn by Holmgren $(1911,1912)$ than he refuted, and one may guess that future studies of taxonomy and phylogeny will verify from 80 to 90 per cent of the relationships indicated by Ahmad. As knowledge of termite evolution has advanced, the geographical relations of the genera have become far more consistent and orderly.

The present paper deals with the distribution of the genera of termites in the major zoogeographical regions. Many principles of interest to ecologists, geographers, and evolutionists emerge from the compiled data. Further refinement of interpretation may be expected from the study of the distribution of species in their ecological niches (see Allee and Schmidt, 1951). Spot maps of the geographical records of each species in each genus have been prepared by the author, but much rechecking of the taxonomy and distribution needs to be done before these maps are ready for publication. In the present study, the data are recorded in a tabular analysis (Tables 1-8) that is designed to document a brief summary of tentative conclusions (Emerson, 1952a) and to bring my tabular analyses up to date (Emerson, 1928). Since the tables were constructed, Harris (1954) has described two new species of Procryptotermes and Amitermes from Socotra Island in the Ethiopian region.

Records of new genera and new species have been included in the tables, thereby rendering the geographic conclusions more secure. The new manuscript genera will be described in the near future. Some genera will doubtless be subdivided into several genera with further study, but most of the named genera can be considered as well established. Complete collections available for study are a necessity for accurate information. The collection of termites belonging to the American Museum of Natural History (Table 1) and now in my custody contains more than 85 per cent of the known named species and about 87 per cent of the known named and unnamed species. More than 70 per cent of the named species of the world are represented in this collection by primary type speci- 
mens (holotypes, paratypes, cotypes, neotypes). The collection, at the end of 1954, contained 1,418 species, of which 818 were represented by all castes (Anoplotermes and Speculitermes without a soldier caste are included), 86 by imago alone, 507 by soldier alone, 2 by worker alone, providing the species was described from the worker, and 5 fossil species. In addition to the named species, the collection also contains 375 new species awaiting description. A high proportion of the genera and species has been verified, but there are probably a number of errors that will be corrected within the collection in the future in addition to the errors in the literature that can be corrected only by re-examination of types or accurately determined specimens. Collections of duplicates have been deposited in Chicago Natural History Museum, the United States National Museum, the Naturhistoriska Riksmuseet, the British Museum (Natural History), and several regional institutions.

\section{TERMS}

Introduced species include those species presumably transported through the agency of man. These may be recognized by their occurrence in the constructions of man and by their species identity on two sides of a natural barrier. Some twenty species of Kalotermitidae and Rhinotermitidae have been temporarily established through human agency in areas outside their native habitat. These are often of great economic importance. They give strong indications of ecological barriers to natural dispersal, both physical and biotic. In the tables introduced species are not included in the regions to which they were transported but are listed only in their native region. They need separate consideration and study.

Native species include species found in their native habitat or in a man-modified habitat in close proximity to their natural occurrence. The tables include only the distribution of native species.

Cosmopolitan genera include those genera found in all of the major zoogeographical regions. Kalotermes and Neotermes as now constituted are the only genera in this category. Neotermes is included, although the only species found in the Nearctic region has its center of distribution in the Neotropical region. Amitermes is not known from the Papuan region but is otherwise a cosmopolitan genus. Microcerotermes is cosmopolitan except for its absence in the Nearctic region.

Tropicopolitan genera include those genera found in all of the major zoogeographical regions with a tropical climate (without freezing 
temperatures in the termite microniche) and absent from the Palaearctic and Nearctic. Glyptotermes, Termes, and Nasutitermes are the only such genera. They may occasionally penetrate subtropical or warm temperate areas at high altitudes, or temperate extensions in the southern portions of the tropical regions. Coptotermes is also classified as a tropicopolitan genus, although it has one species that extends beyond its tropical center into southern Japan. Neotermes comes very close to this category, but it is not included because it has one species extending into temperate Florida, one species in the Madeira Islands, and one species in the Ryu-Kyu Islands.

Overlapping genera are those found in two or more major zoogeographical regions.

Endemic genera are those genera found only in a single major zoogeographical region.

Relict genera are those that show primitive structure and are considered to be ancient forms that have not evolved much or rapidly (bradytelic) since their origin. Relict genera have few surviving species but were once probably widespread, with numerous species. The best example among termites is Mastotermes darwiniensis Froggatt, which belongs to a monotypic family but once was a widespread genus, as attested by the fossil evidence (Table 3). The endemic Archotermopsis and its related endemic genera within the Termopsinae also belong to this category, but only the ancestral genera were possibly widespread. Occasionally relict genera may have survivors in several major regions. Examples are Stolotermes and Porotermes.

Semi-relict genera are those that indicate competitive reduction in numbers but still have numerous species. They typically inhabit several major regions, including Australia. Usually the numbers of species do not indicate the region of origin, possibly because of proportionately greater extinction of species in ancient areas of abundance. Examples are Kalotermes, Neotermes, and Heterotermes.

Relatively primitive endemic genera are members of successful specialized subfamilies that were unable to disperse from the region of origin when climatic highways were available, probably because of competitive biotic barriers. Genera in this category include the more primitive members of the major subfamilies of Termitidae. Examples are Protohamitermes to Eurytermes (Amitermitinae), Hoplognathotermes to Megagnathotermes (Termitinae), Acanthotermes to Synacanthotermes (Macrotermitinae), Syntermes to Rhynchotermes (Nasutitermitinae), and Paracornitermes to Curvitermes (Nasutitermitinae). 
Medium-specialized genera are those midway between the relatively primitive endemic genera and the specialized endemic genera. They are typically widespread and overlap several major regions. These genera appear to have risen from the relatively primitive genera in their respective subfamilies but, unlike their immediate ancestors, they were able to penetrate the biotic barriers that confined the more primitive forms. These genera often exhibit more obviously specialized defensive adaptations in the soldier caste, although their penetration of new regions may be partially due to greater or more versatile adaptation to the physical environment as well as to their biotic environment. Some of these genera show a significant distributional difference in numbers of species. The largest number is usually found in the region of origin as indicated by the distribution of their somewhat more primitive prototypes. However, because of ecological adjustments or for obscure reasons, the largest number of species does not always indicate the region of origin. Examples of medium-specialized genera are Glyptotermes, Coptotermes, Schedorhinotermes, Microcerotermes, Amitermes, Termes, Odontotermes, s. str., and Nasutitermes. It may also be concluded that some ancestral medium-specialized genera now extinct were replaced by specialized endemics. Modern relatives of these unknown medium-specialized genera are Promirotermes, Paracapritermes, Capritermes, Angularitermes, and Subulitermes. In some instances an ancestral genus may be very close to or identical with the modern relative. For instance, Schedorhinotermes is probably very similar to the ancestral genus that gave rise to the neotropical specialized genera, Rhinotermes, Dolichorhinotermes, and Acorhinotermes, and might thus be considered a medium-specialized genus that was eliminated in the Neotropical region by its own specialized descendants.

Specialized endemic genera are those that arose from mediumspecialized genera. These genera are thought to be confined to one region because of climatic or geological barriers at the time of their origin. Examples are Eucryptotermes, Rhinotermes, Dolichorhinotermes, Acorhinotermes, Hoplotermes, Ahamitermes, Globitermes, Cephalotermes, Cylindrotermes, Drepanotermes, Gnathamitermes, Orthognathotermes, Cavitermes, Paracapritermes, Homallotermes, Quasitermes, Pericapritermes, Neocapritermes, Longipeditermes, Velocitermes, Constrictotermes, Tumulitermes, Angularitermes, Subulitermes, Ceylonitermellus MS, Australitermes MS, Eutermellus, and Malagasitermes MS. 
The Australian region includes both tropical and south temperate Australia, Tasmania, and New Zealand. For some animals, New Zealand should probably be considered a separate region, but the two endemic species of termites show an ancient faunal connection with Australia, possibly during the Triassic or Jurassic. The termite fauna of Australia becomes reduced in the temperate areas but the zones are not sharp and all genera except Stolotermes and Porotermes clearly are derived from the tropical fauna. Freezing temperatures are usually local and not prolonged except in higher altitudes and in Tasmania, and the little competition from other termites has not prevented a southern extension of the northern tropical groups.

The Papuan region includes New Guinea, Aroe Islands, Moluccas, Amboina (all east of Weber's Line), and the Pacific islands of Melanesia, Micronesia, Polynesia, and Juan Fernandez (for convenience), but excludes New Zealand, Galapagos, and Cocos. The single endemic termite on Juan Fernandez is tentatively placed in Neotermes without clear affinities. The Hawaiian termites all show derivation from the western oceanic islands and the Indomalayan region but have probably all been introduced. A significant demarcation between an eastern oceanic and a western fauna with continental affinities occurs east of the Fiji and Samoan Islands.

The Indomalayan region has also been referred to as the Oriental region. It includes the tropical Asian continent from western India, southern China just north of Burma, and the southern coast of China, through the tropical islands of the Pacific from Formosa, the Philippines, and East Indies to Weber's Line west of the Moluccas. The distribution of the Macrotermitinae most clearly exhibits the limits of this region to the north and east. Timor and Celebes are included, but Amboina, the Moluccas, and New Guinea are excluded. The western boundary is the temperate steppes and deserts of Afghanistan and Iran. Subtropical northern India and Pakistan south of the Himalayas has an Indomalayan fauna clearly related to the more southern tropics. Temperate altitudes in the Himalayas, Assam, and Indochina have a Palaearctic fauna particularly characterized by Archotermopsis, Hodotermopsis, and Reticulitermes.

The Palaearctic region includes Africa north of the Tropic of Cancer and temperate Asia north and west of the Indomalayan region. It contains the steppes and deserts of Iran, Afghanistan, and the Near East. Europe and North Africa are clearly Palaearctic, as are also the temperate highlands of Asia. A local tropical pocket 
in the Jordan Valley is included in the Palaearctic, although it has elements of an Ethiopian flora and fauna, including a species of Angulitermes.

The Ethiopian region includes tropical Africa and offshore islands south from the Canaries, the Sahara Desert, Sudan, and southern Arabia. Fernando Po, San Thomé, Socotra, Zanzibar, Pemba, and Mafia have a typical Ethiopian fauna. The temperate Cape region of South Africa is included as an extension of the tropical Ethiopian region. The termites of temperate and subtropical South Africa are derived from the tropical genera to the north, with the possible exceptions of Stolotermes, Porotermes, and Microhodotermes.

The Malagasy region includes Madagascar, Europa Island, Comores, Seychelles, Mauritius, Reunion, and, for convenience, CocosKeeling. Cocos-Keeling would not be included in the Malagasy region for most of its fauna, but a Malagasy species of Prorhinotermes is found there. These Indian Ocean islands have a related termite fauna that is distinct from that of the Ethiopian fauna from which their major elements were derived. Because of both the presence and absence of certain termite genera, the Malagasy region deserves separate status. All its native species are endemic, and two monotypic endemic genera are known from Madagascar.

The Nearctic region includes temperate and subtropical North America north from the highlands of Mexico and the lowlands north of the Tropic of Cancer except the Bahamas and the southern tip of Florida. A small amount of overlap between tropical and subtropical species occurs in southern Florida and the Florida Keys. The Bermuda fauna (all probably introduced) is southern Nearctic. As in the case of the Palaearctic region, the genus Reticulitermes marks the southern boundary of the Nearctic and extends northward to about the $49^{\circ} \mathrm{F}$. annual isothermal line. In southern Florida, Reticulitermes extends to Key West.

The Neotropical region includes tropical North America from the Tropic of Cancer south along the Mexican shores, the southern tip of Florida from the vicinity of Miami south, Bahamas, West Indies, Cocos Island, Galapagos Islands, and tropical Central and South America. Temperate South America has a termite fauna clearly derived from the Neotropical fauna with the exception of Porotermes in Chile. The south temperate extensions of otherwise tropical genera in southern Brazil, Uruguay, Argentina, and Chile are the reason for including the whole of the area occupied by termites within the Neotropical region. In general, the northern 
faunal border is sharp and coincides with the northern distribution of Nasutitermes and the southern distribution of Reticulitermes. The boundary is sharp at the altitude of 2,300 feet west of the city of Vera Cruz in Mexico. There is some overlap of Neotropical and Nearctic species in southern Florida and one species of Neotermes with a center of distribution in the tropics reaches Seminole County, Florida, about half the length of the state from the southern tip of the mainland.

\section{ECOLOGICAL ZOOGEOGRAPHY OF TERMITE GENERA}

Termites are now a predominantly tropical order of insects. Some species readily invade southern subtropical and warm temperate regions such as southern Australia and Tasmania, southern Africa, and southern South America, but these species, in most instances, are clearly related to those in the northern tropical regions. The demarcation line between the tropical and subtropical faunas is much more sharp in the north on all continents under both dry and humid conditions. A rapid reduction of species occurs at temperate altitudes on tropical mountains, but a few otherwise tropical genera such as Odontotermes may cross the boundary at high altitudes.

Wholly temperate genera are few in number and all except Gnathamitermes of southwestern United States and temperate Mexico belong to the more primitive families below the Termitidae. It is noteworthy that the surviving relicts of the primitive family Hodotermitidae are largely temperate in their distribution and the fossils indicate Tertiary temperate habitats. In no case are the climatic areas with cold winters and cool summers occupied by termites. The $49^{\circ} \mathrm{F}$. annual isothermal line of both hemispheres encloses almost all native species.

Many genera are primarily tropical in distribution but may have one or a few subtropical or warm temperate species. Such genera are Procryptotermes, Cryptotermes, Neotermes, Calcaritermes, Coptotermes, Heterotermes, Anoplotermes, Procornitermes, and Nasutitermes. The latter two genera invade the subtropics only in the southern hemisphere.

Some genera are mainly tropical but have several species in warm temperatê regions, particularly in the northern hemisphere. These include Kalotermes, Microcerotermes, Eremotermes, Amitermes, and Tenuirostritermes. 
The greatest abundance of species and genera occurs in the humid tropics, particularly in tropical rain-forests. The periodically dry tropical and temperate grasslands have a less abundant termite fauna than their more humid forested counterparts in the same temperature zones. Tropical savannas, however, have a fairly large number of species and genera that are confined to this biome. Some typical genera adapted to grasslands, steppes, and deserts are Paraneotermes (1 species), Hodotermes (2 species), Microhodotermes (3 species), Anacanthotermes (3 species), Psammotermes (3 species), Drepanotermes (2 species), Gnathamitermes (4 species), Synacanthotermes (2 species), Allodontermes (6 species), Procornitermes (6 species), Paracornitermes (4 species), Trinervitermes (60 species), and Coarctotermes (16 species).

A few genera are confined to arid regions. Anacanthotermes and Psammotermes are examples. Psammotermes seems to have maintained this adjustment since Eocene times, when it probably became established in Madagascar. By a study of the time of separation, it is possible to determine the ecological adaptations of genera over long periods of geologic history.

Genera wholly confined to rain-forests are too numerous to list. Some notable genera with species in both savanna and rain-forests are Kalotermes, Procryptotermes, Glyptotermes, Heterotermes, Microcerotermes, Amitermes (a typical genus of dry semi-deserts, steppes, and savannas, but including a few species confined to rain-forests, such as Amitermes excellens Silvestri in British Guiana and Brazil), Apicotermes, Termes, Macrotermes, Odontotermes, Microtermes, Syntermes, Cornitermes, and Nasutitermes. The different species belonging to each of these genera are confined to a climatic vegetational type, with few exceptions.

It is obvious from the distribution patterns of termites that temperature and moisture are the major physical factors that limit their dispersal. These two factors largely determine the vegetation types or biomes also, so that a high degree of correlation between phytogeography and termite zoogeography is apparent. There seems to be a tendency for termite species to be correlated with the distribution of plant genera, and for termite genera to be correlated with the distribution of plant families, while plant species are usually much more local than are termite species. The reason for this type of correlation may be that plants are more sensitive to small ecological variations of a greater variety of factors than are termites, which exert considerable social control over their microclimates 
within their nests and burrows so that they can tolerate greater fluctuations in their extra-social environment.

Another important ecological factor that is often underemphasized by biogeographers is competition for limited necessities. The role of competition in the dispersal of termites is only partially understood even though its importance seems great. There seems to be much unexploited food for termites in many habitats with a rich fauna, so it is possible that competition for colonizing sites and for nesting sites is greater than for the nutritive resources. This may mean that, in many cases, competitive factors are greater between species of termites than between termites and other animals. Some circumstantial evidence for this hypothesis is to be found in the restriction to the man-modified habitats of introduced species of termites. Some twenty species, all belonging to the Kalotermitidae and Rhinotermitidae, have been inadvertently transported by man in his wood products and in the soil attached to living plants. When these termites are introduced to regions climatically similar to the areas from which they came, the species may become established, often causing great economic damage to human constructions. Typically the introduced species are unable to invade the native environment, but remain confined to the constructions of man. It seems probable that competition with native species is a biotic barrier to the spread of introduced species. Islands, which have a depauperate termite fauna, seem to be more propitious for the establishment of introduced termite species than are tropical continental regions with a numerous and varied termite fauna. Predators, parasites, and other phylogenetically unrelated organisms, besides competition with related species, may be involved in the production of biotic barriers. It will be noticed in the following discussion that biotic factors are invoked to explain aspects of modern distribution on a par with either geological or climatic factors.

The distribution of genera and higher categories indicates the more important ecological factors, but many more subtle limitations to dispersal may be detected by a study of each species. To cite a rather extreme example, colonies of Termes inquilinus (Emerson) are found only in the arboreal nests of Constrictotermes cavifrons Holmgren, and colonies of the closely related Termes fur (Silvestri) are found only in the nests of Constrictotermes cyphergaster (Silvestri). Obligatory inquilines are rare among termites, but they indicate the complexity of ecological adjustment that sometimes determines distribution. Future ecological zoogeographical studies of species rather than genera, particularly by investigators with a thorough 
knowledge of local habitats, will add much detail to the broad generalizations suggested in this paper and will correct errors that almost certainly are present in a summary treatment of this type.

THE RELATIONSHIPS OF THE TERMITES OF ZOOGEOGRAPHICAL REGIONS

The generally recognized zoogeographical regions also exhibit high correlations of their termite faunas. Each has been geographically or climatically isolated from the others at various times during its Mesozoic and Tertiary history, and the termite faunas give qualitative and quantitative indications of these periods of continuity and isolation.

The total number of termite species in each of the tropical regions arranged in order of decreasing abundance duplicates the order of land area from largest to smallest. This correlation is much more obvious for the Rhinotermitidae and Termitidae than for the more primitive families composed largely of relicts or semi-relicts. Abundance of species is also roughly correlated with the variety of habitats and ecological opportunity offered to termites during their long history, together with the limitations imposed by interspecies competitive relations between the termites themselves. This correlation of abundance and area breaks down in the temperate regions because of the influence of the temperature factor. Within the tropical zone, a continental area with rain-forest, savanna, and woodland will have more species than an area with a single vegetational type. The species decrease with increasing aridity and with the agricultural and social activities of man. Although long-isolated islands are likely to have endemic native species, small islands usually have depauperate faunas, even when montane conditions offer a fair variety of habitats.

In the following discussion of each region, I have attempted to offer simple hypotheses to account for modern distributions of the genera and higher categories. The basic data are listed in the tables (Tables 2-8). For details of distribution and phylogeny, the reader is referred to papers by Holmgren $(1911,1912)$, Hare (1937), Ander (1942), Snyder (1949), Ahmad (1950), Ross (1953), and Emerson $(1925,1928,1933,1942,1945,1947,1950,1952 \mathrm{a}, 1952 \mathrm{~b}, 1953)$. The suggested hypotheses rest upon circumstantial evidence, often with data insufficient for much more than speculations. However, it seems to me that the bulk of information and correlations is fairly consistent with the hypotheses and that evidence from other analyses, particularly from mammalian paleontology, phylogeny, and 
geography, is slowly accumulating to an impressive degree. Doubtless much future revision of the present tentative conclusions will be made in the face of more abundant and more accurate data, but statements of working hypotheses consistent with known facts form a base for an advancing science of biogeography. The stated conclusions are likely to be over-simplifications and some will probably have to be replaced by more complex explanations. It is hoped that this compilation of data and theory will stimulate others to gather relevant information about other groups of organisms, particularly when taxonomic and phylogenetic information is sound.

Australian region. - The Australian termite fauna is statistically more closely related to the Ethiopian than to any other, but if the two relict genera with possible antarctic dispersal are eliminated, the data then indicate equal relations with the Papuan, Indomalayan, and Ethiopian regions. These data suggest that Australia is a peripheral region with a Mesozoic fauna that probably arrived from Indomalaya directly or through New Guinea.

Nearly half of the Australian genera belong to the families below the Termitidae. All of these primitive genera may be presumed to have originated in the Permian or Mesozoic and a number of relicts and semi-relicts possibly arose in early or middle Mesozoic. Two, Stolotermes and Porotermes, possibly reached Australia through a southern antarctic land mass in Triassic times. Stolotermes is now found in New Zealand, Tasmania, and eastern Australian temperate and tropical habitats. Porotermes is in southeastern Australia and Tasmania. Mastotermes could conceivably go back to the Permian, but it doubtless came into Australia from the north, where the family was probably cosmopolitan in the Mesozoic and Tertiary periods. The single living species of Mastotermes occurs locally in subterranean and somewhat dry habitats in both east and west Australia north of the Tropic of Capricorn. It is absent from rainforests and areas once covered by rain-forests (Ratcliffe, Gay, and Greaves, 1952).

The Kalotermitidae of Australia and New Zealand all belong to widely spread genera that probably entered Australia in the Jurassic or early Cretaceous from Eurasia through the ancient Papuan connections. None of these genera indicate the region of origin except Glyptotermes, which possibly originated in the Neotropical region. Australian Glyptotermes are only found in the somewhat more humid areas of the east, both north and south of the Tropic of Capricorn. Of the four genera of Rhinotermitidae, all probably reached Australia in early Cretaceous times from Indomalaya through the Papuan, 
and three give indications of having originated in the Indomalayan region. The place of origin of Heterotermes is obscure. No relatively primitive genera of Termitidae or its subfamilies occur in Australia. Four are widespread genera that invaded Australia from the north via Indomalaya in early Cretaceous. The origin of Microcerotermes seems to have been in Africa. Nasutitermes surely came from South America via a tropical Bering bridge. The origin of Amitermes is obscure. Most species of Amitermes are found in Africa, but the more primitive relatives are Indomalayan. The origin of Termes is likewise obscure. Most species are Australian, but a large series of more primitive relatives are exclusively Ethiopian. Nine specialized endemics, all Termitidae, presumably arose in Australia in late Cretaceous or Tertiary times from medium-specialized ancestry invading from Indomalaya. There is no indication of any arrivals in Australia since mid-Cretaceous, when the sea barrier at Weber's Line was probably established. However, a dry climate or competition may have eliminated some of the genera that came in early Cretaceous. It is noteworthy that the two most highly specialized groups of termites, those with asymmetrical snapping mandibles in the soldier and those with nasute soldiers, have endemic Australian genera (Paracapritermes, Tumulitermes, Australitermes MS, etc.), which indicate the dispersion of their immediate ancestral types by mid-Cretaceous.

Papuan region.- It might be expected that the Papuan fauna would be more closely related to the Australian than to any other region, but actually the relationships are closer to Indomalaya. In part, this may be due to incomplete collections, but some of the genera overlapping with the Indomalayan did not reach Australia or were eliminated after reaching it. These include Prorhinotermes, Capritermes, Grallatotermes, Hospitalitermes, and possibly Leucopitermes MS. Also, none of the endemic genera of Australia are reported from the Papuan region. Some of these may ultimately be found, but for the present the barrier seems fairly sharp. No endemic genera are known from the Papuan region, and the statistical data indicate that it is a peripheral region with a generic fauna originating elsewhere, either in Indomalaya or reaching the Papuan region through Indomalaya, with the exception of Rugitermes.

The Kalotermitidae are well represented, and four of the genera with obscure origins possibly arose in the Jurassic and spread to the Papuan region during the Jurassic or early Cretaceous. Glyptotermes is possibly a late Jurassic or early Cretaceous invader through a northern tropical connection with its Neotropical region of origin. 
Rugitermes has reached only the eastern oceanic islands. The genus probably arose in the Neotropical region in early Tertiary times and was able to reach the eastern edge of the Papuan region over the seas by some unknown means. All other Papuan genera, including those in the eastern oceanic islands, probably dispersed from the western Papuan region and Indomalaya. All the genera of the Rhinotermitidae are clearly extensions from Indomalaya during the early Cretaceous. All except Heterotermes give numerical evidence of their Indomalayan origin. All of the Termitidae doubtless came from Indomalaya during the Cretaceous and probably most originated in Indomalaya. However, Microcerotermes indicates an Ethiopian origin, Nasutitermes came from the Neotropical region over the Bering bridge, and Termes has an obscure geographical origin, although its more primitive relatives center in Africa. Neotermes and Prorhinotermes have the largest number of species in the Papuan region, but this may well be due to island endemism rather than a Papuan origin. Some Papuan genera are known only from New Guinea, Moluccas, and Aroe Islands. These include Heterotermes, Parrhinotermes, Termes, Capritermes, Grallatotermes, Hospitalitermes, and Leucopitermes MS. Others may occur from New Guinea and the Solomons east to Samoa. These include Schedorhinotermes, Microcerotermes, and Nasutitermes. It is zoogeographically significant that a highly specialized physogastric staphylinid termitophile of the genus Thyreoxenus lives in the nests of Nasutitermes in the Solomon Islands (Seevers, 1937). These termitophiles do not accompany the colonizing pair of termites but invade the mature colonies of their hosts several years after the founding flight. This means that the termites that flew over wide water-gaps and managed to find mates after the flight would tend to leave the specialized termitophiles behind. This contention is borne out in the case of the island-hopping species of Nasutitermes in the Lesser and Greater Antilles. It seems to me that the existence in the Solomons of a Neotropical termitophile genus like Thyreoxenus in the nests of a host genus, Nasutitermes, that originated in the Neotropics strongly suggests tropical land continuities or short water-gaps in the past. If Thyreoxenus is found in Indomalaya in the future, further presumptive evidence of Cretaceous land connections or contiguities will be indicated.

Genera of termites reaching the eastern oceanic islands east of Samoa from the west include Kalotermes, Procryptotermes, Cryptotermes, Neotermes, Glyptotermes, and Coptotermes, while Rugitermes reached the eastern islands from South America. Prorhinotermes 
has a distribution among the Papuan islands similar to Schedorhinotermes, but inasmuch as it occurs in Cocos, Central America, and the West Indies, it is to be expected in the eastern Polynesian islands.

Indomalayan region.-It is noteworthy that the large tropical continental regions have a smaller percentage of overlapping genera and a larger percentage of endemic genera than the temperate or peripheral and smaller regions (Tables 7,8 ). This fact probably indicates that the larger tropical continental regions are the centers of origin of a larger proportion of existing genera, particularly those genera that arose in Cretaceous or Tertiary times. The Indomalayan region stands somewhat below the Ethiopian or the Neotropical regions in this respect. Nevertheless it stands high as either a primary or a secondary center of termite evolution. The Indomalayan fauna is statistically closer to the Ethiopian and is almost as close to the Papuan followed by the Neotropical. There are no endemic genera of Mastotermitidae, Kalotermitidae, or Hodotermitidae in the Indomalayan, nor is there a significantly larger number of species of the overlapping genera of these families. However, these indications of a center of origin tend to disappear with age, so it is by no means impossible that important groups of termites originated in this region during the early and middle Mesozoic but have left no discernible evidence of these events. When we examine the data on the Rhinotermitidae and Termitidae, we do find some evidence of Indomalayan origins. Two of the seven Rhinotermitid genera are endemic, and three of the five overlapping genera have more species in Indomalaya. Of the remaining two genera, Heterotermes has an obscure place of origin and Prorhinotermes might conceivably have originated in the Indomalayan in spite of the larger number of Papuan species, possibly because of the essential limitation of this genus to islands and speciation through island isolation. The only other region with more endemic Rhinotermitids is the Neotropical with four such genera, but the three in the subfamily Rhinotermitinae are clearly specialized genera derived from a stock very close to Schedorhinotermes, a genus that gives clear indications of an Indomalayan origin. It is true, however, that the two most primitive genera in the Psammotermitinae are not found in Indomalaya. The absence of Psammotermes may be due to ecological conditions and one cannot attach too much significance to the absence of Glossotermes or a related primitive genus. One may conclude, therefore, that present indications are that the Rhinotermitidae had its main center of origin and dispersal in the Indo- 
malayan, and that this family probably arose from an extinct ancestral group sharing the generalized and primitive mandibles of the most primitive Hodotermitids and the ocelli that doubtless occurred in primitive ancestors of termites and are retained in all families except the Hodotermitidae.

The most generalized of the subfamilies of the Termitidae seems to be the Amitermitinae. The evidence indicating a center of origin is not as clear as in the other Termitid subfamilies but there is sufficient to suggest an Indomalayan origin. Eleven genera, including seven endemic genera, are found in Indomalaya-more than occur in any other region. One of the endemics is Protohamitermes, unfortunately only known from imagoes and workers of one species from Sarawak. In spite of the paucity of material and information, this genus shows striking affinity to the mandibular pattern of the Rhinotermitidae and may be considered the most primitive genus of the Termitidae. Of the four overlapping genera, Speculitermes has more species in the Neotropical, Microcerotermes has more species in the Ethiopian, Eremotermes has an equal number of known species in the Palaearctic but probably originated in the Indomalayan, and Amitermes has the largest number of species (36) in the Ethiopian, followed by Australia (27) and the Neotropical (11), while only three occur in the Indomalayan. The more primitive relatives of Amitermes are Indomalayan genera, so this inconsistency in order of species abundance is possibly a result of speciation in response to ecological conditions rather than an indication of the center of origin and dispersal.

All of the six Indomalayan genera of Termitinae, including the four endemic genera, are medium-specialized or specialized types. The subfamily probably originated in the Ethiopian region and invaded Indomalaya in early Cretaceous times. Termes seems to have had a secondary center of speciation in Australia, but it possibly originated in Africa. The highly specialized Capritermes seems to have originated in the Indomalayan, where 32 species now occur, and dispersed in the Cretaceous to New Guinea and through Africa to Madagascar by Eocene times.

Fourteen genera of Nasutitermitinae occur in Indomalaya; nine are endemic, and all are medium-specialized or specialized groups. The primitive genera of this subfamily are exclusively Neotropical, and it seems clear that the remote ancestors of the Indomalayan genera came from the New World. The only extant genus still found in the two regions is the tropicopolitan Nasutitermes, which 
must have dispersed in early Cretaceous over a tropical Bering bridge. Consistency of species numbers gives evidence of the place of origin and the direction of ancient dispersal. Corroborative evidence is also found in the phylogeny and dispersal of the staphylinid termitophiles, a thorough study of which is soon to be published by Dr. Charles Seevers. Somewhat more primitive genera than Nasutitermes are endemic in Indomalaya. Hirtitermes and Longipeditermes seem to have arisen from an extinct group that arrived in Indomalaya at about the same time as Nasutitermes. This stock radiated to produce Grallatotermes and Hospitalitermes in early Cretaceous times, when they probably spread to the Papuan region. The same stock produced the endemic Bulbitermes and Lacessititermes in Indomalaya, Coarctotermes in the Ethiopian and Malagasy regions by Eocene times, and Constrictotermes in the Neotropics, possibly from an ancestral genus that dispersed back to the New World in the late Cretaceous. On a sub-branch of the subfamily, Havilanditermes is closely related to Indomalayan Nasutitermes, and Ceylonitermes shows a relationship to the Central American and $\mathrm{Ne}-$ arctic Tenuirostritermes that possibly arrived in the orient in Tertiary times, and to Trinervitermes that probably had its origin in the Ethiopian region when a tropical savanna was established in the Miocene. Trinervitermes has five species in India and Ceylon, and one questionably assigned species in Indochina. It appears most likely that Trinervitermes invaded India from Africa in the Miocene or, more probably, in the Pliocene, through a tropical savanna or steppe corridor. Four genera of small termites on the Subulitermes branch of nasutes occur in Indomalaya, all endemic except one that has a tentatively included species in Amboina. These came from two stocks from the Neotropics that also reached Australia and Africa, and one reached Madagascar by Eocene times.

It appears from these considerations that Indomalaya was an important secondary region of origin and dispersal of an original Neotropical subfamily, and that several independent invasions of Indomalaya occurred during early Cretaceous times.

The Indomalayan region has a larger proportion of original dry and humid forest lands than any other tropical region, and this fact together with the modification by dense populations of humans has doubtless influenced its known termite fauna. Collections from still unmodified habitats such as Borneo are very much needed.

Palaearctic region.-The Palaearctic termite fauna shows its closest relations to the Ethiopian and next to the Indomalayan. This indicates the origin of many of the genera in the contiguous 
southern tropics. The north temperate regions are characterized by depauperate termite faunas, as might be expected for animals with a tropical adjustment. However, a number of interesting relicts occur in the Palaearctic, and in the case of the Hodotermitidae these are possibly indicative of a temperate origin of this primitive family. An alternative possibility is widespread competitive elimination by higher termites in the tropics. The abundance of species of termites decreases north of the tropical border, and no records are known north of $43^{\circ} \mathrm{N}$. Lat. in Asia and $48^{\circ} \mathrm{N}$. Lat. in Europe. The Tertiary fossils indicate warm temperate conditions as far north as $55^{\circ}$ Lat., but in no case give evidence of a tropical climate. To explain the present distribution of termites, it is necessary to postulate tropical climates as far north as the Bering land bridge at about $60^{\circ}$ Lat. during the Cretaceous and Jurassic periods. It is hoped that isotope determinations of sea temperatures from Mesozoic fossils together with paleobotanical data will soon verify this conjecture based upon the circumstantial evidence of termite distribution.

Thirteen genera of termites are recorded from the Palaearctic, of which over half are from the more primitive families below the Termitidae. Eleven genera are overlapping and only two are endemic. The endemics are the two very primitive relicts, Archotermopsis of the temperate Himalayas and Hodotermopsis of subtropical altitudes of Indochina and subtropical latitudes of the Ryu-Kyu Islands. In a number of particulars, including the dentition of the imago mandibles, Archotermopsis is the most archaic living termite. One fossil species is found in Eocene Baltic amber. A more primitive genus, Termopsis, is also known from Baltic amber as well as from other European deposits of Oligocene and Miocene age. It is probable that the Termopsinae arose in temperate Eurasia, possibly in early Mesozoic times, and in the Mesozoic reached North America, where fossil and living derivative genera are known from the Oligocene of Colorado. Microhodotermes, with two species in North Africa and the Near East, also probably arose in the subtropical Palaearctic and moved south through the highlands of Africa to give rise to the single species in subtropical South Africa. Anacanthotermes is a subtropical desert genus extending through North Africa to the border of India, with one species in a dry area of southern India. The genus presumably originated in the southern Palaearctic steppes and deserts and dispersed eastward to tropical Indomalaya. The Oligocene and Miocene fossil genus Ulmeriella seems to belong to the Hodotermitinae with four Eurasian species 
and one known from the state of Washington. Possibly this extinct genus also arose in the temperate Palaearctic and reached North America in the Miocene or earlier.

The species of Palaearctic Kalotermes were probably.derived from the nearest tropical regions, although Kalotermes is found in many subtropical latitudes over the world and has long had temperate representatives, as evidenced by several European Tertiary fossils tentatively assigned to this genus. Neotermes is essentially a tropical genus but has a single Palaearctic species in the Madeira Islands and one Indomalayan species that reaches Okinawa in the Ryu-Kyu Islands near $26^{\circ} \mathrm{N}$. Lat. Psammotermes in the North African desert seems to be derived from Ethiopian ancestors. Coptotermes has one species in southern Japan that is also known from tropical Formosa and China and is doubtless descended from Indomalayan species. Reticulitermes is the only Holarctic genus, and the nearly equal numbers of recorded species in Eurasia and in North America do not indicate the center of origin. Species are known from Eocene Baltic amber, so we may assume at least an early Tertiary history as a temperate genus. The closest genus is the somewhat more primitive Heterotermes with an obscure origin in the tropics, possibly in late Jurassic or early Cretaceous. All records of Reticulitermes south of the Tropic of Cancer are at temperate altitudes. Five species of $M i$ crocerotermes occurring in the steppes and deserts of North Africa and southern Asia were all probably derived from an ancient Ethiopian center. Eremotermes in North Africa and the south Asiatic steppes and deserts possibly had its origin in Indomalaya. Amitermes has five species in North Africa and in the steppes and deserts of southern Asia. For reasons explained elsewhere, it is difficult to state that the Palaearctic species came from either Africa or India, in spite of the much larger number of Ethiopian species. The single Palaearctic species of the Termitinae is found near Jericho in the tropical Jordan Valley of Palestine. This species is a northern extension of an Ethiopian genus. Its presence indicates tropical conditions or at least subtropical conditions in the Jordan Valley during the last glaciation in Europe, and also indicates a continuous extension of tropical climate through Egypt at the time of its establishment in Tertiary or Pleistocene times.

During the Mesozoic and Tertiary, tropical climates must have connected the Indomalayan and Ethiopian regions through what is now southern Palaearctic Asia. The large majority of the genera that moved along this corridor are typically savanna and steppe types, but a few probably required more humid conditions. Nasu- 
titermes probably required forests in the Cretaceous, and the forest types of Macrotermes were dispersed in mid-Tertiary, possibly in the Miocene.

Ethiopian region.-As is to be expected, the Ethiopian termite fauna as a whole is most closely related to the Indomalayan. Tropical Africa is probably the major center of evolution of termite genera, although it is not necessarily the most ancient center, because most of the genera originating or dispersing from an Ethiopian center belong to two advanced subfamilies of Termitidae, the Termitinae and the Macrotermitinae, the first originating in the Cretaceous and the second in post-Eocene Tertiary. The Ethiopian genera of Kalotermitidae are all widely dispersed genera with only one, Glyptotermes, that gives any indication of the region of its origin, which was possibly in the Neotropics.

The relict species of Stolotermes and Porotermes in temperate South Africa may indicate an origin in a temperate Antarctic land mass during the Triassic, as discussed elsewhere. Hodotermes is a tropical steppe genus that invades the subtropical areas of South Africa. It is known from only two species confined to Africa, but all other genera of the Hodotermitidae seem to be adapted to temperate climates and it may be guessed that Hodotermes is descended from a Mesozoic Palaearctic ancestry or possibly from an extinct tropical genus. The single species of Microhodotermes in subtropical South Africa has two related species in the Palaearctic steppes and deserts and presumably reached South Africa by way of highlands through central Africa at some unknown geologic period. The single southeast species of Psammotermes is related to a North African temperate and tropical desert species and also to a southwestern Madagascar steppe species, a fact that indicates a dispersion from Africa at least by Eocene times. The Ethiopian Coptotermes probably came from a center of origin in Indomalaya during the Cretaceous. The single Ethiopian species of Heterotermes recorded from Abyssinia is possibly an introduction from Central America. Schedorhinotermes seems to have originated in Indomalaya in the Cretaceous, but it may not have reached tropical Africa until postEocene times, because it is unrecorded from Madagascar.

The Ethiopian Amitermitinae consist of seven genera, four of which are monotypic endemic genera, of which only one, the rainforest Cephalotermes, has a fairly well-recorded distribution. Many species of Anoplotermes are now known throughout tropical dry and wet areas and extend into subtropical South Africa. This genus has more species in the Neotropical region but strangely is unknown 
from either Indomalaya or Madagascar. Its origin and time of dispersion must remain speculative, but an Indomalayan highway during the Cretaceous seems most likely. Microcerotermes has the largest number of species from Africa and is abundant in both humid and dry tropical and subtropical climates. The numbers of species are consistent in their order and indicate a northern dispersal from Africa during the Cretaceous. Its more remote ancestors, however, probably came into Africa from Indomalaya. Amitermes also has the largest number of species in the Ethiopian region and is adjusted to dry tropical and warm temperate climates. In Africa, the species are absent from the rain-forests. The origin of the genus was probably Cretaceous and was possibly Indomalayan, although the numbers in each region are not consistent and the place of origin is obscure.

The Termitinae have 34 endemic genera in the Ethiopian region starting with the relatively primitive Hoplognathotermes. I found eight new genera recently in the Belgian Congo. Fifteen genera from Hoplognathotermes to Megagnathotermes have a relatively primitive morphology, while 19 of the genera from Cubitermes to Orthotermes are relatively somewhat more specialized but still retain biting mandibles in the soldier. Genera from both groups may be either dry savanna or wet forest types and a few genera such as Apicotermes and Cubitermes are found in a variety of climatic conditions from Senegal to South Africa. It must be presumed that primitive genera of Termitinae originated before the Cretaceous dispersal of the medium-specialized genera with snapping mandibles in the soldier. Some of the existing genera with biting mandibles in the soldier may have originated in Tertiary times when the African fauna was isolated, but it is difficult to understand why some relatively primitive forms are not found in other regions, particularly in Madagascar. The single genus, Spinitermes, in South America with biting soldier mandibles is a possible exception to this distribution pattern, but it needs more exact phylogenetic study. The most primitive of those soldiers with symmetrical snapping mandibles is Promirotermes, now confined to the Ethiopian region. A slightly more specialized genus, Termes, is tropicopolitan with the largest number of species in Australia and otherwise not presenting a consistent order of abundance. It must be assumed that this genus spread to Australia and to South America during early Cretaceous times along with a stock close to Promirotermes that gave rise to related genera now endemic to the Neotropical region. The African and Palestinian Angulitermes also arose from such a stock 
or possibly from Termes itself. The genera with asymmetrical snapping mandibles are also derived from a base close to Promirotermes, but the existing genera with the exception of Capritermes are specialized endemics in every tropical region. Pericapritermes is the Ethiopian representative of this group.

The fungus-growing termites or Macrotermitinae are clearly of Ethiopian origin from some extinct group that shared the primitive characters of both the Macrotermitinae and the Nasutitermitinae and was itself probably derived from the primitive Amitermitinae. All ten genera of the Macrotermitinae are Ethiopian, including the primitive endemic rain-forest Acanthotermes and its close relative, the rain-forest and savanna Pseudacanthotermes. The genera that dispersed to the Indomalayan region, probably at the time of the Miocene extension of grasslands, all have the greater number of species in Africa. Some species of forest Macrotermes in Indomalaya give slight evidence of forest continuity. The European fossil from the Miocene assigned to Macrotermes needs generic verification. The most specialized genus, Microtermes, a diminutive forest and savanna genus, became established in Madagascar by some unknown means, most probably during the post-Eocene Tertiary. The subfamily as a whole seems to have originated in Oligocene times, subsequent to the isolation of the Malagasy fauna in the Eocene. It is the only subfamily of termites with an indicated Tertiary origin.

The Nasutitermitinae have ten Ethiopian genera. All are medium-specialized or specialized genera and, so far às can be seen, all have an Indomalayan ancestry in the Cretaceous and a more remote Neotropical ancestry in the early Cretaceous. The genus Nasutitermes arose in the Neotropics and moved across the tropical Bering bridge to the tropical orient and thence to Africa. In Africa the species remain in the forested areas and ecologically do not overlap with Trinervitermes locally. Grallatotermes arose in Indomalaya and probably reached the east coast of Africa in the Cretaceous or early Tertiary. Trinervitermes arose in Africa, probably with the Miocene savannas. It is absent from the rain-forests but is abundant from the northern tropical desert borders to the subtropical Cape. A species has recently been reported from Aden in the Arabian peninsula. A few species seem to have dispersed to India and Ceylon in the Miocene, or more probably in the Pliocene, and one that needs verification is reported from Indochina. Coarctotermes is an African and Malagasy genus that arose in the African dry environments in the early Tertiary before the Eocene isolation of the fauna of Madagascar. Its more primitive nasute ancestor came from Indomalaya, 
where it has several endemic relatives. Its ancestral genus may have arrived in Africa at the same time as its relative, Grallatotermes, but Coarctotermes is better adapted to dry conditions and is a more successful group in Africa. Mimeutermes is a bizarre little genus reported from Guinea and the Gold Coast in moderately dry climates. It is the only African genus of the Paracornitermes-Subulitermes branch with points on the reduced soldier mandibles. Its remote ancestry came from the Neotropics in Cretaceous times. A somewhat more primitive relative has recently been found in Madagascar, indicating the extinction or possibly the lack of discovery of other relatives in Africa. Eutermellus and a group of related undescribed nasute genera without pointed soldier mandibles are rain-forest genera on the Subulitermes branch of the Nasutitermitinae. The ancestors of this group also reached Africa through Indomalaya from a remote origin in the Neotropical Cretaceous. The nasute termites do not seem to be quite as successful in Africa as they are in their Neotropical center of origin, while the Termitinae that originated in Africa show decreasing success as they moved farther from their native land. One may guess that these rough negative correlations of abundance between these two subfamilies may be the result of competition between specialized termites, with the more ancient and locally better-adapted species maintaining themselves against the later invaders that were less well adapted to the local conditions at the time of invasion. The nasute termites, which possess specialized adaptive defense apparatus, are usually more successful than any other equivalent group of tropical termites, but in Africa the Termitinae seem to have the ascendancy. With our meager information on termite competition, however, such hypotheses are highly speculative.

Malagasy region.- The bulk of the termite fauna of the Malagasy region shows clear affinity to the Ethiopian fauna and may be presumed to have originated from Africa in the late Eocene (Beaufort, 1951). Moreau (1952) postulates an Eocene connection with Africa that broke in late Miocene, but the termite and mammalian faunas appear more consistent with a late Eocene separation. So far as termites are concerned, there is no need to postulate dry land connections, but only a faunal exchange over a much shorter watergap than now exists. All the termites in native habitats are specifically distinct, with the exception of one species of Cryptotermes that was possibly introduced from Africa by early man. This species, C. havilandi (Sjöstedt), is geographically incompatible with another species of Cryptotermes in Madagascar soon to be described by Lena 
Moszkowski, and possibly had no close competitor in its dry wood habitat in the comparatively moist regions of the island at the time of introduction. Not only are all Madagascar species endemic, with the exception of the introductions, but local endemism occurs in many isolated islands such as Europa, Mauritius, Reunion, Seychelles, etc. Also there are two endemic genera. Besides these indications of long isolation from exchange with Africa, there are a large number of genera in southeastern Africa that are absent from Madagascar. The sharp faunal demarcation provides the reason for giving full regional status to the Malagasy region.

No Mastotermitidae or Hodotermitidae are recorded. The Kalotermitid genera include about a third of all the species, a proportion that indicates geographic and ecologic peripheral distribution. All could have been directly derived from African congeners. A noteworthy species among the Rhinotermitidae is Psammotermes voeltzkowi Wasmann, which retains the generic adjustment to arid habitats characteristic of the genus in Africa. Coptotermes could easily have come through Africa from the Orient. The single species of Prorhinotermes is an exception to the usual derivation from Africa. It probably arrived in Madagascar via the sea, and all the Indian Ocean island records seem to be referable to a single species except for an endemic species in Ceylon. $P$. canalifrons (Sjöstedt) has been found on Madagascar, Anjouan, Moroni, Mahé, Long Island, Preslin, Amiranten, Poivre, Aldabra, Mauritius, Chagos Archipelago, and Cocos-Keeling. This wide range for a single species indicates continual or recent interbreeding, so that the sea seems to be no barrier to dispersal in this case. No species of this genus is known from Africa.

Nineteen species of Microcerotermes are now known from the Malagasy, mostly from Madagascar itself. The recently described genus Gibbotermes Cachan (1951) is not generically distinguishable from Microcerotermes. The largest number of species of this genus is recorded from the Ethiopian region and many are found in South Africa. A single new species of Amitermes is now known, adding Madagascar to the distribution of this widespread genus with its adaptations to arid conditions. No primitive Termitinae are known, but Termes has a single Madagascar species and Quasitermes is a specialized endemic genus with somewhat asymmetrical snapping mandibles showing affinities to endemic genera in Australia, Indomalaya, and the Neotropical region. It may be presumed that the ancestral stock in Africa is now extinct or has been missed by collectors. Capritermes with two species is an example of peripheral oc- 
currence of a genus otherwise known from many Indomalayan species and a single species in New Guinea. Capritermes probably evolved in the tropical orient in the Cretaceous period and spread in two directions, with one branch moving through Africa to Madagascar in the Cretaceous or early Tertiary but later becoming extinct in Africa. Four or five species of Microtermes are found in Madagascar. This zoogeographical problem is discussed under the section on anomalies. Nasutitermes has ten species, indicating an early successful invasion through Africa of this tropicopolitan genus. Coarctotermes with five species is otherwise found only in the Ethiopian savannas and steppes. A new genus, Malagasitermes MS, is endemic to Madagascar and is the only genus from the Subulitermes branch of the Nasutitermitinae known from Malagasy. Its closest relative is also a new genus, Leucopitermes MS, from Indomalaya and also possibly from Amboina. A more remote relative is Mimeutermes in Africa.

It seems to me that the Malagasy termite fauna is a segment of the Eocene Ethiopian fauna with subsequent Tertiary evolution of the endemic species and two endemic genera. The isolated region during middle and late Tertiary received Microtermes and Prorhinotermes over sea barriers and, since the establishment of man, has acquired several introduced species. This postulated history of the termite fauna fits well with the mammalian pattern, which also indicates the isolation of an Eocene fauna with some sporadic entrance of a few species across the strait and, of course, recent introductions by man.

Nearctic region.-With the notable exception of Reticulitermes and the relict $Z$ ootermopsis, the termite species and genera seem to have their closest affinities to those of the Neotropical region. One may postulate a tropical fauna that was extensive over North America during the Mesozoic but receded southward into the tropics during the whole of the Tertiary. The Bering land bridge to Eurasia was the major route of dispersion in both directions during the Mesozoic, but the cool temperate climate precluded termite spread throughout the Tertiary for all except the temperate-adjusted genera. Even the temperate genera may have dispersed in Mesozoic times, but some could have moved over warm temperate highways in the Tertiary. There is no indication that any termite used a north Atlantic bridge during the Tertiary.

The number of species and genera diminishes rapidly with decrease in the annual temperature. A few termites reach southern 
Canada in Ontario and British Columbia. Most of the species are found only in the warm temperate or subtropical habitats, and a few genera may be confined to either the mesic Gulf states or to the dry southwest.

No Mastotermitidae are now living in the Nearctic, but Mastotermes is recorded from the Eocene of Tennessee. The only Kalotermitid genus with more than one species is Kalotermes, a genus that is either zoogeographically or ecologically peripheral in its present distribution. It may be successful in the warm portions of the Nearctic region because of the lack of competition to which it would succumb in the richer tropics. Procryptotermes has a single southwest species, the only temperate species of the genus. Cryptotermes has a single Florida species, also the only native temperate species of the genus. Paraneotermes is a monotypic endemic genus of Mexico and southwestern United States, but it seems to be confined to damp wood even in the dry semi-deserts. It is descended from Kalotermes. Neotermes, also descended from Kalotermes, has one species in middle Florida and southward into the West Indies. Calcaritermes has one Florida species probably dispersed from Central America along the Gulf coast during a warm interglacial period, possibly the last interglacial. Zootermopsis is an endemic Nearctic genus with three species, two in coastal and montane Pacific Coast states and Nevada, and one in Arizona in damp logs and large stumps along watercourses. The genus is descended from a Palaearctic ancestry represented by relicts. An allied genus, Parotermes, is known from the Oligocene of Colorado in strata that also preserved a termite wing tentatively assigned to Zootermopsis. These termites could have reached North America in Tertiary temperate climates, but their primitive morphology and disjunct distribution make a Mesozoic dispersal a possibility. The only other North American Hodotermitid is a Miocene wing from Washington state assigned to Ulmeriella. Two genera of Rhinotermitidae are Nearctic. Heterotermes has two species in the southwestern United States and Mexico in the subsoils and dead plants of arid habitats. Reticulitermes is a Holarctic genus with six North American species distributed according to soil temperature and moisture through mesic forests, prairies, and semi-deserts. The time and place of origin of the genus are obscure, but fossils are known from the Eocene of Europe and the Oligocene of Colorado. Reticulitermes overlaps into the Neotropical region only at the southern tip of Florida and along the keys to Key West. In Mexico the distribution is sharply limited at the border of the Neotropical. The northern limits of the genus 
coincide fairly well with the $49^{\circ} \mathrm{F}$. annual isothermal line. Anoplotermes has one Nearctic species as far north as southern Texas. Amitermes has several species in the arid grasslands and semi-deserts of the southwest and Mexico. Gnathamitermes, with four species in the arid southwest and Mexico, is an indigenous genus, probably an offshoot from Amitermes. Tenuirostritermes is the only nasute genus, probably originating in the Neotropics where most of its species still occur in Central America.

Neotropical region. - Statistically the Neotropical termite fauna is most closely related to that of the Ethiopian. With the removal of Porotermes and Rugitermes for reasons discussed elsewhere, the closest affinity would be Indomalayan followed by the Ethiopian and Australian. Next to the Ethiopian region, the Neotropical has the largest number of termite genera and species and has been a major center of origin and dispersion. All indications point to a tropical climate with both humid and dry habitats well back into the Mesozoic. The mammalian data and history indicate an Eocene separation from North America that lasted into mid-Pliocene when the Panamanian isthmus arose and allowed considerable movement of animals both north and south. The termite fauna rather diagrammatically fits into the historical pattern of mammalian origin and dispersion as outlined by Simpson, with two major exceptions. The termites typically are tropical insects, while many groups of mammals had a temperate origin and dispersal. And even without corroborative fossils, many termite genera give indications of having arisen and dispersed in the Mesozoic earlier than or contemporaneous with early marsupial evolution. Only the more specialized genera of termites show geographic patterns similar to those of tropical families of placental mammals that arose in the early Tertiary.

No Mastotermitidae are now known from the Neotropical region, but fossil wings from the Pliocene of Minas Gerais in Brazil appear to represent a new primitive genus of this family. Eight of the nine genera of Kalotermitidae are known from the Neotropical region and more than twice as many species are recorded as from any other region. These data do not positively prove the origin of the family in this region, but they do indicate a secondary if not a primary center of origin. Kalotermes has 15 species, all found on the shores or offshore islands, a fact that indicates competitive elimination of this genus in regions of high competition. An illustration of such competition is afforded by the occurrence of Kalotermes in the mangrove swamps of Panama and its absence in the 
rain-forests of the isthmus where more specialized Kalotermitidae occur. The independence of these dry-wood termites from the soil also reduces their competition with the soil termites of the Rhinotermitidae and Termitidae. Procryptotermes needs further study before geographic generalizations can be made with confidence. Cryptotermes, in spite of its specialized phragmotic soldier, shows an ecological peripheral distribution in South and Central America, but seems to succeed a little better than Kalotermes in highly competitive regions. In Panama, the common introduced Cryptotermes dudleyi Banks has not invaded the native habitats since 1890 . Possibly the native Cryptotermes create a biotic barrier. Neotermes is a successful damp wood genus in interior as well as peripheral areas. Rugitermes probably arose in the Neotropical region but has managed to establish two endemic species in the eastern oceanic islands of the Papuan region. Rugitermes is largely confined to subtropical and tropical South America with an extension north to Costa Rica, a distribution that indicates a post-Eocene origin in South America and a sharply limited extension northward at the time of the Pliocene emergence of the isthmus of Panama. This limitation is not climatic and is more likely to be biotic in its nature. Eucryptotermes is a highly specialized monotypic endemic genus about which little is known beyond its occurrence in Santa Catarina and its morphological relations with a Neotermes-like base. Its phragmotic soldier is convergent with that of Cryptotermes and Glyptotermes. Glyptotermes is a tropicopolitan genus, but the largest number of species is Neotropical, followed in consistent order of numbers with other regions along the lines of dispersion. This fact may imply a somewhat later origin than the more primitive Kalotermitidae that do not show a significant order of abundance of species. A late Jurassic or early Cretaceous dispersal would be the most plausible. Glyptotermes occurs in subtropical Brazil and Argentina but is mainly tropical. Calcaritermes centers in Central America with one species in Nearctic Florida and some in northern South America. Recently one new species has been found on Ilha Grande near Rio de Janeiro, casting some doubt on the hypothesis that the genus arose in Central America in post-Eocene times and dispersed into South America in the late Pliocene.

The only Hodotermitid in the region is the Chilean temperate Porotermes, with a possible dispersal through Triassic Antarctica.

Glossotermes is tentatively placed at the beginning of the Rhinotermitidae, but its origin and affinities are rather obscure. It is known from a single soldier from the British Guiana rain-forest. 
Coptotermes seems to have come from Indomalaya, possibly in the Cretaceous. Heterotermes does not give evidence of its phylogenetic or geographic origin, but its dispersion also may have been Cretaceous or possibly Jurassic. Prorhinotermes is found fairly close to the sea in Cocos, Central America, and in tropical Florida and Cuba. The origin seems to have been in the western Pacific and dispersal has followed sea routes rather than land routes. Possibly it moved in floating logs through the early Pliocene seas connecting the Atlantic and Pacific. Rhinotermes, Dolichorhinotermes, and Acorhinotermes are a related series of genera derived from an Indomalayan stock close to Schedorhinotermes. The direction of the ancestral dispersion seems to have been from the Old World to the New World over the Cretaceous Bering bridge. All three genera are South American except for the extension of Dolichorhinotermes into Panama and the island-hopping of Rhinotermes marginalis (L.) from South America up through the Lesser Antilles to Haiti over water-gaps no greater than ninety miles and possibly less during the Pleistocene glaciation. The patterns suggest a post-Eocene origin of the genera of Rhinotermitinae in South America.

The Amitermitinae are represented by several medium-specialized or specialized genera. Speculitermes is a soldierless termite with a single recorded species in India and six in the Neotropical rain-forests and savannas. The phylogeny and geographical origin of this group are not well understood. Speculitermes may be the ancestral genus of Anoplotermes. The latter genus has a very large number of species in South and Central America. Anoplotermes has a most peculiar distribution, with a single Nearctic species and a large Ethiopian fauna. By its absence from Indomalaya and Madagascar, it is unique among genera not relicts or semi-relicts that overlap between Africa and South America. Any hypothesis as to its time or place of origin must remain speculative until more information has been gathered. Hoplotermes is a monotypic Mexican genus with its closest affinity to the somewhat more primitive Indomalayan Eurytermes. Microcerotermes indicates by the number of species that it had a Cretaceous origin in Africa and dispersed through Indomalaya to the New World over the Bering bridge. Cylindrotermes is an endemic rain-forest genus of South America with a Pliocene extension to Panama. It appears to have evolved from a stock related to the Indomalayan Prohamitermes and the Ethiopian Cephalotermes. Amitermes has several Neotropical species, most of them found in the dry savannas and deserts. However, two species are common in the rain-forests, one in Panama and the other in Guiana and Brazil. 
The rain-shedding structures on trees constructed by the latter species are remarkable behavior adaptations. Amitermes dispersed in the Cretaceous, but its place of origin is obscured by its ecological specialization. One species from southern South America has been erroneously placed in Synhamitermes, but needs further study before it is given a generic assignment.

Eleven genera of Termitinae occur in the Neotropics, eight of which are either medium-specialized or specialized genera. Spinitermes is the only genus with typical biting mandibles in the soldier that is found outside of the Ethiopian region. The imago mandibles are quite specialized and appear to show relationship to the African Ophiotermes and Tuberculitermes, but this similarity may be convergent. The imago mandibles of Orthognathotermes are more primitive than those of Spinitermes, but the soldier has a peculiar type of partially biting and partially snapping mandibles. The endemic Genuotermes has a slightly more primitive soldier than Orthognathotermes, but its recently discovered worker mandibles are more specialized. The phylogeny of these Neotropical genera needs to be carefully studied before zoogeographical hypotheses can be made. The group is remotely related to the relatively primitive Ethiopian Termitinae, but so far no intermediates are known that could furnish a clue to the time of origin and dispersal. Spinitermes and Genuotermes are confined to tropical South America, while Orthognathotermes reaches Panama to the north and the subtropical savannas of Brazil and Paraguay to the south. This suggests that the ancestors reached South America before the Eocene isolation and that the three genera developed their modern generic distinctions during the post-Eocene Tertiary. The Neotropical genera Dentispicotermes, Spicotermes, Termes, Crepititermes, and Cavitermes have symmetrical snapping mandibles in the soldier and seem to be a related group of genera. All but Termes are endemic. From the imago mandible of Spicotermes, it may be presumed that Spicotermes and the slightly more primitive Dentispicotermes are both early offshoots of a basal group related to the African Promirotermes and that the tropicopolitan Termes is somewhat more specialized. We may postulate, therefore, that a somewhat more primitive group of termites than Termes with symmetrical snapping mandibles in the soldier dispersed from Africa at about the same time during the early Cretaceous and reached South America well before the Eocene separation from North America. Termes is the only related genus now found in the tropical regions outside of the Ethiopian and Neotropical, but those genera with asymmetrical snapping mandibles evolved from the 
same primitive stock related to Promirotermes and have established endemic genera in every tropical region. Cornicapritermes is an endemic genus with a frontal projection, a frontal gland, and strongly asymmetrical mandibles in the soldier. Neocapritermes and Planicapritermes, without either a frontal projection or a gland, I now consider to be the end product of the evolution of the Termitinae. Both Ahmad (1950) and I (Emerson, 1950) placed them at the beginning of the Termitinae because of their seemingly primitive imago-worker mandibles and in spite of the soldier specializations, but it would now appear that the so-called primitive imago-worker mandibles are convergent to a type somewhat similar to Euhamitermes and Cephalotermes in different respects. The Ethiopian Pericapritermes indicates the reduction in size of the apical tooth also characteristic of Neocapritermes, but the sharp angle between the first and second marginal teeth of the right mandible is not found in any other Termitinae.

The Nasutitermitinae originated in the Neotropical region by early Cretaceous times and had already evolved the specialized nasute soldier by the early or the mid-Cretaceous when nasutes with a diphyletic reduction of the mandibles dispersed around the tropical world. The ancestry of the Nasutitermitinae is not very clear because of the extinction of the groups that connect this subfamily with the other Termitidae. I gave evidence (Emerson, 1945) for an ancestral relationship between the Nasutitermitinae and Macrotermitinae and guessed that this primitive stock emerged from the primitive Amitermitinae. This phylogeny is speculative. After the origin of the Nasutitermitinae, however, the phylogenetic and geographic history seem to be correlated. The most primitive existing genus is Syntermes, with morphological indications of relationship to Procornitermes. From a base related to Procornitermes, two branches split, one leading through stock giving rise to the mandibulate genera of Cornitermes and Rhynchotermes on to nasute genera of the Nasutitermes branch. The other branch split off from a Procornitermes-like base and gave rise to the mandibulate genera, Paracornitermes, Labiotermes, Armitermes, and Curvitermes. Nasute genera emerged from this branch, the most primitive of which is Angularitermes, followed by a number of genera found around the tropical world. It is significant that the eight relatively primitive mandibulate genera in both branches are wholly Neotropical. All except Cornitermes, Rhynchotermes, and Armitermes are wholly South American. Cornitermes reaches north to Costa Rica, and Rhynchotermes and Armitermes both reach Honduras. The Central American 
extensions are probably Pliocene or Pleistocene dispersions from continental South America. All these genera are Tertiary relatives of a basic Cretaceous mandibulate stock, and the series indicates gradations in the double origin of the nasute soldier type in early Cretaceous South America. Nasutitermes is representative of the genera that spread throughout the tropical world before the midCretaceous isolation of Australia. It may be presumed that the dispersion from the New World to the Old was across the Bering land bridge under favorable moist tropical climates. The failure of the relatively primitive mandibulate genera to move to the Old World under the same favorable climatic conditions may be explained by biotic barriers that could be penetrated only by the highly defended nasute genera. In all probability several nasute genera moved at the same time as Nasutitermes, because endemic genera in Indomalaya, somewhat more primitive than Nasutitermes, presumably arose from a nasute base that is now extinct, and endemic nasute genera of the Subulitermes branch, both with points and without points on the vestigial mandibles, arose from extinct groups with a South American origin. It is noteworthy that the order of abundance of species in Nasutitermes is entirely consistent with this hypothesis. One species of Nasutitermes extends from northern South America through the Lesser Antilles to the Greater Antilles. Another species of Nasutitermes occurs in northern South America, Central America, and east of Yucatan through the Greater Antilles to the Virgin Islands. The route of dispersal to the West Indies may have been through Yucatan in this case, but the Lesser Antilles seem to have been utilized for island-hopping dispersion to a greater degree by termites. There is a tendency for these species of Nasutitermes to leave their specialized termitophiles behind when they fly over wide water-gaps, but more thorough collecting is necessary before strongly supported conclusions can be drawn. Six endemic nasute genera on the Nasutitermes branch are now Neotropical and all except Constrictotermes presumably originated in the New World. Rotunditermes and Diversitermes are South American derivatives of a Nasutitermes-like base. Diversitermes occurs in tropical and south temperate savannas. Velocitermes is a close relative of Diversitermes, with both tropical savanna and rain-forest species. It extends to Panama in Central America and has two endemic species in Haiti, an indication of a post-Eocene origin and Tertiary dispersion by way of the Lesser Antilles. Tenuirostritermes seems to have a center of origin and dispersion in Central America. A few species have extended north into Nearctic Mexico, Texas, and Arizona. One 
species in Venezuela may indicate a southern extension in the late Pliocene. Ceylonitermes in Ceylon seems to be a fairly close relative of Tenuirostritermes and may indicate a possible Tertiary extension of a temperate-adapted genus. Parvitermes is a small genus confined to the West Indies except for a tentatively included species from Bolivia. Obtusitermes is a small genus in the forests of Panama, Venezuela, Trinidad, and Cuba. Constrictotermes has slightly more primitive relatives in the Indomalayan region, where much secondary evolution and dispersion of nasute genera occurred. It is a possibility that the ancestor of Constrictotermes moved into South America from Indomalaya in late Cretaceous times after the isolation of Australia in mid-Cretaceous and before the Eocene isolation of South America. The present meager evidence for this hypothesis may be supplemented in time by a study of the highly specialized termitophiles known to inhabit the nests of these related genera.

Angularitermes is a primitive nasute now found in the rain-forests of northern South America and is close to the base that presumably dispersed around the world in the Cretaceous and gave rise to many endemic genera in the tropical regions. In South America this stock gave rise to several endemic genera, including Subulitermes and Convexitermes, none of which are found north of Panama. These genera may be considered post-Eocene derivatives of a basic early Cretaceous stock with a Neotropical center of origin and dispersal.

The small monotypic and endemic subfamily of Serritermitinae is confined to South America. It has a peculiar combination of primitive characters such as large wing stubs in the imago and large but unpigmented eyes in the soldier, together with such specialized characters as the bizarre elongated and serrate soldier mandibles and the extremely modified imago mandibles. The origin and relationships of this species must remain obscure until more data are discovered.

\section{ANOMALIES OF TERMITE DISTRIBUTION}

Our knowledge of historical geology, paleoecology, taxonomy, phylogeny, and evolutionary processes all seems to provide evidence for a reasonable interpretation of the causes of contemporary world distribution of termites as outlined in the preceding pages. However, there are numerous instances that do not fit precisely into the expected geographic order. These cases of anomalous distribution are discussed below, together with possible explanations for the discrepancies. The simplest explanations of the known facts may be over-simplifications. The rule of parsimony may actually tend to 
obscure complicated events that determined the present distribution of termites. It may be expected that the biogeography, paleontology, and ecology of many other organisms will ultimately be so correlated as to offer better interpretations of termite zoogeography.

Mastotermes: The lone surviving relict of this genus and the family now is found only in tropical Australia. Australia is a continent containing numerous relicts that cannot compete against more advanced animals, but there is a fairly abundant and advanced competitive termite fauna in the area occupied by Mastotermes. There is no simple explanation for the extinction of the Tertiary representatives of the family over the world and the persistence of the single relict in tropical Australia.

Procryptotermes: This genus is cosmopolitan, except for the absence of any records from the Palaearctic and Indomalayan regions. Only one species occurs in the Nearctic, so the genus may have been absent from the Palaearctic throughout its history. However, it should have been present in the Indomalayan region during Mesozoic and Tertiary times. Possibly it will be found there ultimately.

Rugitermes: This genus probably evolved from a Neotermes-like stock in the Neotropical region during the post-Eocene Tertiary. The occurrence of one endemic species in the Marquesas and Society Islands and another in the Cook Islands indicates a westward dispersion to these eastern oceanic islands that is not duplicated by any other termite genus. Most if not all other native termites in these islands originated in the western Papuan area. Kalotermitidae could be more easily carried in the branches of a floating tree than could the soil-dependent termites of the higher families.

Calcaritermes: The center of dispersal of this genus is Central America. It may be presumed to have originated from Glyptotermes in this area during the Tertiary separation of South and Central America. During late Pliocene the genus could have invaded northern South America, where it is now found. One new species, however, has been discovered on Ilha Grande off the coast near Rio de Janeiro, Brazil, a locality far south of the expected range, if the hypothesis is correct. The single Nearctic species in the northern half of Florida probably arrived from tropical Central America during a warm interglacial period along the Gulf coast. Florida is known to have been broken into low islands or submerged during parts of the Pleistocene.

Stolotermes and Porotermes: These two relict genera belong to different subfamilies and are not closely related, but they both 
represent about the same stage in evolution within the primitive family of Hodotermitidae. Their occurrence at the southern temperate extremities of the continental land masses may be explained by the extinction of congeners dispersed through northern connections, but if so, one might expect some north temperate relicts. All other genera of the Hodotermitidae clearly show north temperate distribution or relationships. One wonders whether these genera in the south temperate areas might be relicts of an Antarctic fauna. Antarctic coal of Mesozoic age is reported. Porotermes and Stolotermes, because of their primitive structure, possibly could have existed in Triassic times. Romer (1952) gives evidence from fossil reptiles for his belief "in the existence of a southern inter-continental connection between South America and South Africa in the Triassic." The termites from such a postulated land mass also reached Australia, Tasmania, and New Zealand. The hypothesis of a northern dispersal is supported by P. J. Darlington, Jr. (personal communication), who cites the instance of Chiasognathinae (stag beetles) that now occur in Australia, New Zealand, southern South America, and South Africa. There are none in the north at present, but there is one in Baltic amber. Ander (1942) also discusses other patterns that parallel Stolotermes and Porotermes.

Hodotermitinae: One might expect relicts of this subfamily to occur in Australia, but none are reported. When any group is reduced to a few species, discontinuities and sporadic occurrence result from extinctions in regions of earlier occupancy. The smaller the number of surviving species, the more likely there will be unexplained inconsistencies. There is no record of any existing species of this subfamily in the New World, but a Miocene wing of Ulmeriella is known from the state of Washington, an indication of a more widespread distribution of the group during the Tertiary.

Heterotermes: This genus is presumed to have arisen before the Cretaceous separation of Australia from Indomalaya. One might expect some records from central and southern Africa and possibly also from Madagascar. The exclusion of this genus from the major portion of the Ethiopian region seems difficult to explain, except by competition with an ecological equivalent. Psammotermes is mutually exclusive but is restricted to dry areas, while Heterotermes may live in rain-forests. Heterotermes has been introduced into Mauritius, Madagascar, and St. Helena, where it succeeds in the climates of these islands. The single record from Abyssinia may also be an introduction. The Galapagos records belong to a common Central American species that may have been introduced. 
Prorhinotermes: The extensive island distribution of this genus and its comparative rarity on continents seem to demand a distribution by means of floating logs or coconuts during Tertiary times or earlier and its exclusion by biotic barriers from richly faunated continents. There is need for study of physiological tolerance to marine transportation - a means to dispersal that seems unavailable to practically all termites. Contemporary dispersal over seas is indicated by the existence of some species in fairly widely separated islands such as many islands in the Indian Ocean, but endemic species on single islands or in small island groups indicate an earlier dispersal and speciation before the advent of man. A hiatus of records between the Samoan Islands and Cocos Island may be filled with more complete collections.

Parrhinotermes: This genus, with a monomorphic soldier, is more primitive than the Old World genus, Schedorhinotermes, with a dimorphic soldier, which in turn antedated the New World Rhinotermitinae with reduced mandibles in the minor soldier. Parrhinotermes probably arose in Indomalaya and dispersed during the Cretaceous to New Guinea and Queensland. It must have been present at the time of the origin and dispersal of Schedorhinotermes, but it did not spread so far. We may presume biotic barriers that did not prevent the better-defended Schedorhinotermes from extending its range.

Schedorhinotermes: The center of origin of this genus was Indomalaya, with a Cretaceous dispersal eastward to the Papuan region, including Palau and Santa Cruz, and south to Australia. The westward movement to the Ethiopian region, however, seems to have occurred later than the Eocene. Otherwise why is the genus absent in Madagascar? An alternative explanation might be the Tertiary or recent extinction of the genus in Madagascar for unknown reasons. An ancestral relative did move to the New World during the Cretaceous to give rise to the Neotropical Rhinotermitinae during the post-Eocene isolation of South America.

Anoplotermes: This genus shares the loss of the soldier caste with the somewhat more primitive Speculitermes. The large number of species in the Neotropical and Ethiopian regions, and the lack of any record in Indomalaya, where one species of Speculitermes is known, present a unique pattern of distribution. These two genera might be expected to have arisen in the Indomalayan region in the late Cretaceous from more primitive Amitermitinae still represented in the tropical orient. It is predicted that Anoplotermes will be 
found in Indomalaya with more concentrated collecting, but its rarity or possible absence in this region seems to have no reasonable explanation, and its absence from Madagascar is also difficult to understand. It is a highly successful genus in the variety of habitats offered in both the Neotropical and Ethiopian regions.

Amitermes: Except for the absence of any record from the Papuan region, this genus is cosmopolitan. Its future discovery in the savannas of southern New Guinea may be predicted.

Angulitermes: The occurrence of a new species of this otherwise Ethiopian genus in a tropical pocket near Jericho in the Jordan Valley in Palestine indicates a past connection of a tropical or subtropical climate through Egypt to the Sudan. Such a climate could have existed during the last interglacial warm period or earlier, but the maintenance of subtropical or tropical conditions in the Jordan Valley during the last glaciation is somewhat difficult to believe.

Capritermes: This genus has 32 species in Indomalaya, one species in New Guinea, and two species in Madagascar. Its absence from the Ethiopian region presents a problem. It may be postulated that Capritermes was present in Africa in early Tertiary or late Mesozoic times and later became extinct, possibly because of competition with a related genus such as Pericapritermes.

Microtermes: All indications point to the origin of the Macrotermitinae in the Ethiopian region later than the Eocene. No explanation seems adequate to account for the existence of five endemic species of the most specialized genus, Microtermes, in Madagascar. It can only be supposed that some sort of unusual dispersal occurred during the Tertiary, across a water barrier that effectively barred all other termites. This problem is the most baffling of all the cases of anomalous distribution.

Coarctotermes: This savanna and steppe genus is found in Africa and Madagascar - an indication of an Eocene dispersal. Why is it not also found in India, to which it could have moved with Trinervitermes? It seems necessary to postulate an unknown biotic barrier. Several related endemics in Indomalaya may have formed a barrier.

Grallatotermes: If this genus originated in the Cretaceous in Indomalaya and reached Mafia Island and Portuguese East Africa by Eocene times, why is it not found in Madagascar? Possibly it will be discovered in more complete collections.

Malagasitermes MS: This new genus includes a single species, "Eutermes" Milloti Cachan (1949, pp. 189, 248). It belongs to the 
Paracornitermes-Subulitermes-Eutermellus branch of the Nasutitermitinae. It has a point still present on the soldier mandible in some cases. Its presence in Madagascar tends to substantiate the theory of the origin of this large branch in the Neotropical region with a Cretaceous dispersal westward to all tropical regions. The closest allied genus, however, is Leucopitermes MS, erected to include "Subulitermes" leucops Holmgren (1914, p. 252), from Sumatra, Borneo, and Java. This genus also tentatively includes "Subulitermes" undecimus Kemner (1931, pp. 34, 36, 37), from Amboina. The African genus Mimeutermes belongs to this group of genera but is much more distant from Malagasitermes than is Leucopitermes. We again note (see Capritermes above) a closer affinity between the Indomalayan and Malagasy termites than the more obvious and more easily explained affinity between the Ethiopian and Malagasy termites on the one hand and the Ethiopian and Indomalayan on the other. The simplest hypothesis would seem to be the extinction or lack of discovery of the intermediate relatives in Africa. The hypothesis of a land connection (Lemuria) across the Indian Ocean does not seem to rest upon sufficient evidence.

The Malagasy Fauna: This fauna of 17 genera, two of which are endemic, and 76 wholly endemic species shows closest affinity to the Ethiopian fauna, followed by the Indomalayan. It is somewhat strange that the presumed Eocene separation of the Malagasy and African faunas did not include relict primitive genera of termites. The subtropical Cape Province of South Africa harbors the relict Stolotermes, Porotermes, and Microhodotermes, and the tropical steppes and savannas have the relict Hodotermes. The lack of relict Hodotermitidae in Madagascar can be explained only by the spotty survival pattern of relict animals in general. The most primitive termites in the Malagasy belong to Kalotermes. This genus is cosmopolitan, although giving evidence of persistence only in ecologic and geographic peripheral regions. It may be guessed that the competitive elimination in regions with rich termite faunas results from association with higher Kalotermitidae rather than the higher families that live in other microniches. The two endemic genera in Madagascar are highly specialized Termitinae and Nasutitermitinae. The lack of relatively primitive endemic relicts of Nasutitermitinae can easily be understood because of the remote origin of the subfamily in the Neotropical region. But the lack of relatively primitive genera of Termitinae that must have originated in the Ethiopian region during the Cretaceous is hard to understand. The hypothesis that such termites could not penetrate the biotic barrier composed 
of locally well-adapted genera seems reasonable when there is an exchange between large faunas, but it is doubtful if a rich endemic termite fauna in Madagascar in the Eocene or earlier can account for the absence of relatively primitive Termitinae, and there is no indication that climatic factors could account for a barrier as they may for some genera in dry Australia.

The Papuan Fauna: The Papuan termites in general reached the region from Indomalaya in the Cretaceous and have produced no specialized endemic genera. Nor are primitive relicts found in the region. The climatic difference between New Guinea and Australia may be responsible for the lack of southward extensions of such moisture-adapted genera as Capritermes, Grallatotermes, and Hospitalitermes into Australia. It is strange that the endemic Australian genera are in no case found in New Guinea. There is no reasonable explanation for the absence of at least some of the following genera from the drier portions of southern New Guinea: Ahamitermes, Drepanotermes, Paracapritermes, Protocapritermes, Tumulitermes, Occasitermes, Macrosubulitermes MS, Occultitermes MS, Australitermes MS. Of these only Tumulitermes is a markedly successful genus with many species in Australia, and a genus with many species has a better chance to spread to another region than one with a highly restricted local range. However, a few of these genera should have been able to invade New Guinea during the Pleistocene connections with Australia. It is predicted that Amitermes and some of the listed Australian endemics will ultimately be collected in the drier habitats of New Guinea.

\section{DISCUSSION}

The suggested hypotheses to account for the known distributional patterns may well be over-simplifications. Fluctuating climates and land emergence and submergence through the millions of years covered by the Mesozoic and Cenozoic eras, together with variations in rate of evolution, vagility, and adaptations of both closely related and remotely related animals, render diagrammatic simplicity and consistent statistical order improbable. The fact that so much order is apparent in the tables of termite distribution and that reasonable hypotheses account for the order and most of the discrepancies is rather surprising. The uniformity of the nutritive adjustments, the weakness of the flight, the pairing subsequent to the flight, the general bradytelic evolution, and the early origin of the order are the probable reasons why termite origins and dispersal are still discernible from neozoological data. Tests, correc- 
tions, and augmentations of the hypotheses will follow (1) accurate determination of all termite species and genera, (2) discovery of fossil termites, particularly of Mesozoic tropical species (see Romer, 1945), (3) accurate study of phylogenetic relationships, (4) knowledge of parallel distributions and phylogenies of plants and animals intimately or broadly associated with termites (see Darlington, 1948), (5) the geologic substantiation of ancient conditions, (6) the accurate determination of comparative vagility (see Simpson, 1952), and (7) further advance in our understanding of evolutionary processes.

\section{CONCLUSIONS}

Termite distributions in general present patterns that correlate with paleogeology, paleontology, ecology, and phylogeny. Simple explanatory hypotheses may stimulate further research and comparison within the developing science of biogeography. 


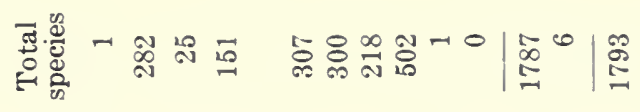

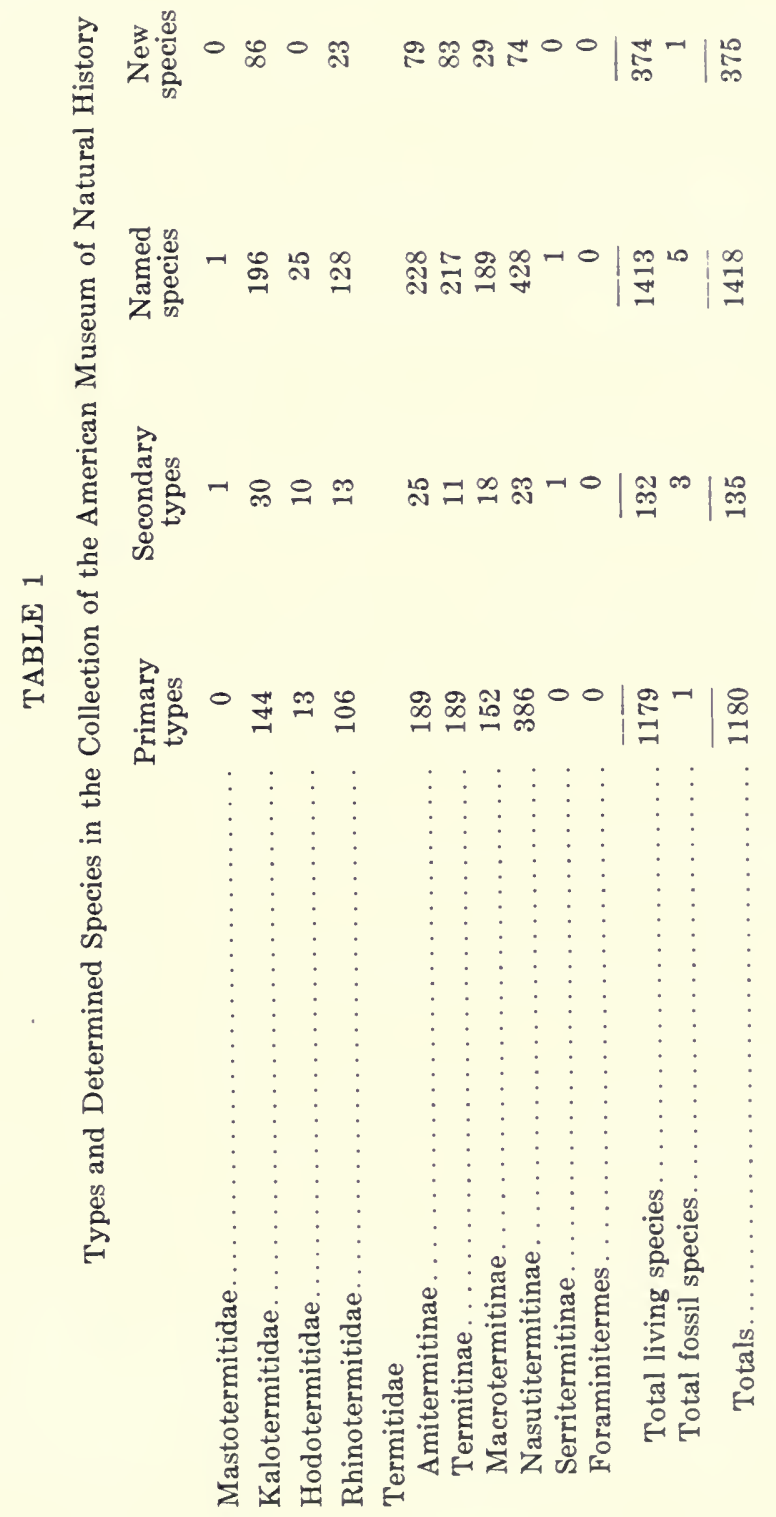




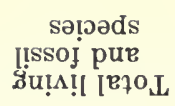

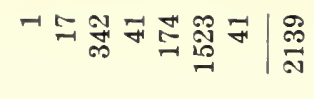

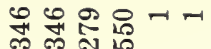

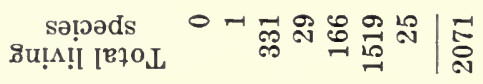

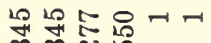
ต

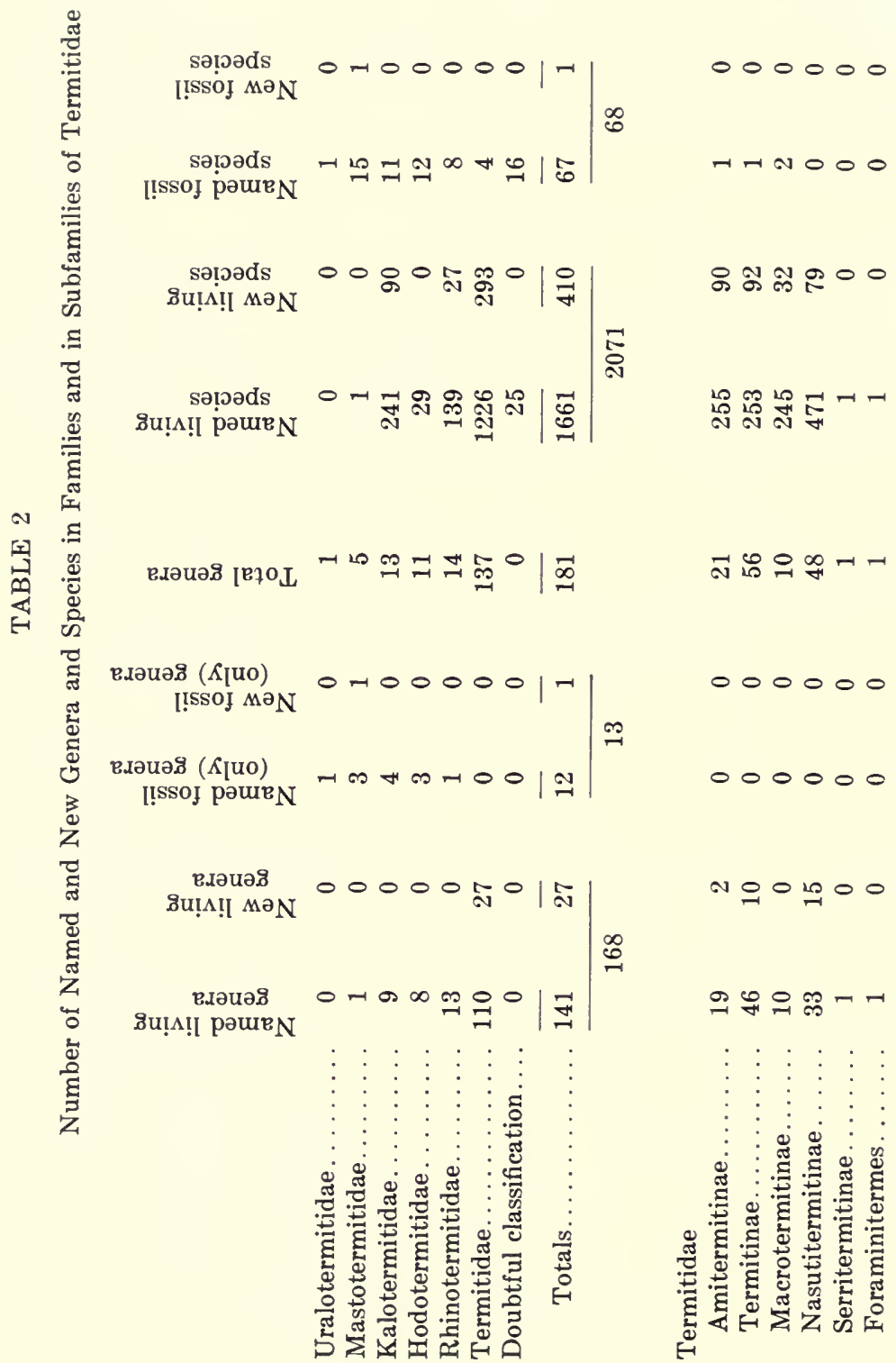


sə̣̣วads [E70J

ー ーのーーか

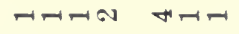
ガーーール゚ CN NRTE

วนวว

-075!วld

วนววอ!ाd

(⿸丆口

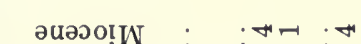

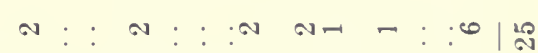

己ֶ,

วนววоฐเป็

$: \infty:-1$

$\neg: \neg: \neg:$ ー

$. \infty \mid \hat{i}$

วนววоร

$: \mathbb{N}::$

$\because \neg: 0 \quad$ ー

$\neg \longrightarrow: \vdots$ !

$N \mid \frac{10}{20}$

ue!̣uдаd -

'มวนU $\cdot \mathrm{S}$

$\cdot$ IวUU $\cdot N$

อวเมี

eISY

odosn

$. \infty-\forall$

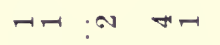

カー : :

ホール：出|

旅

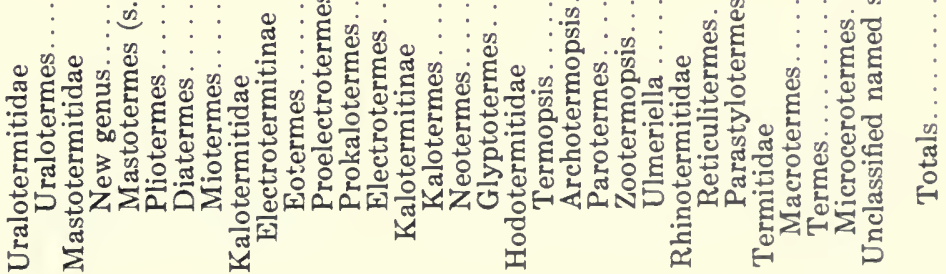




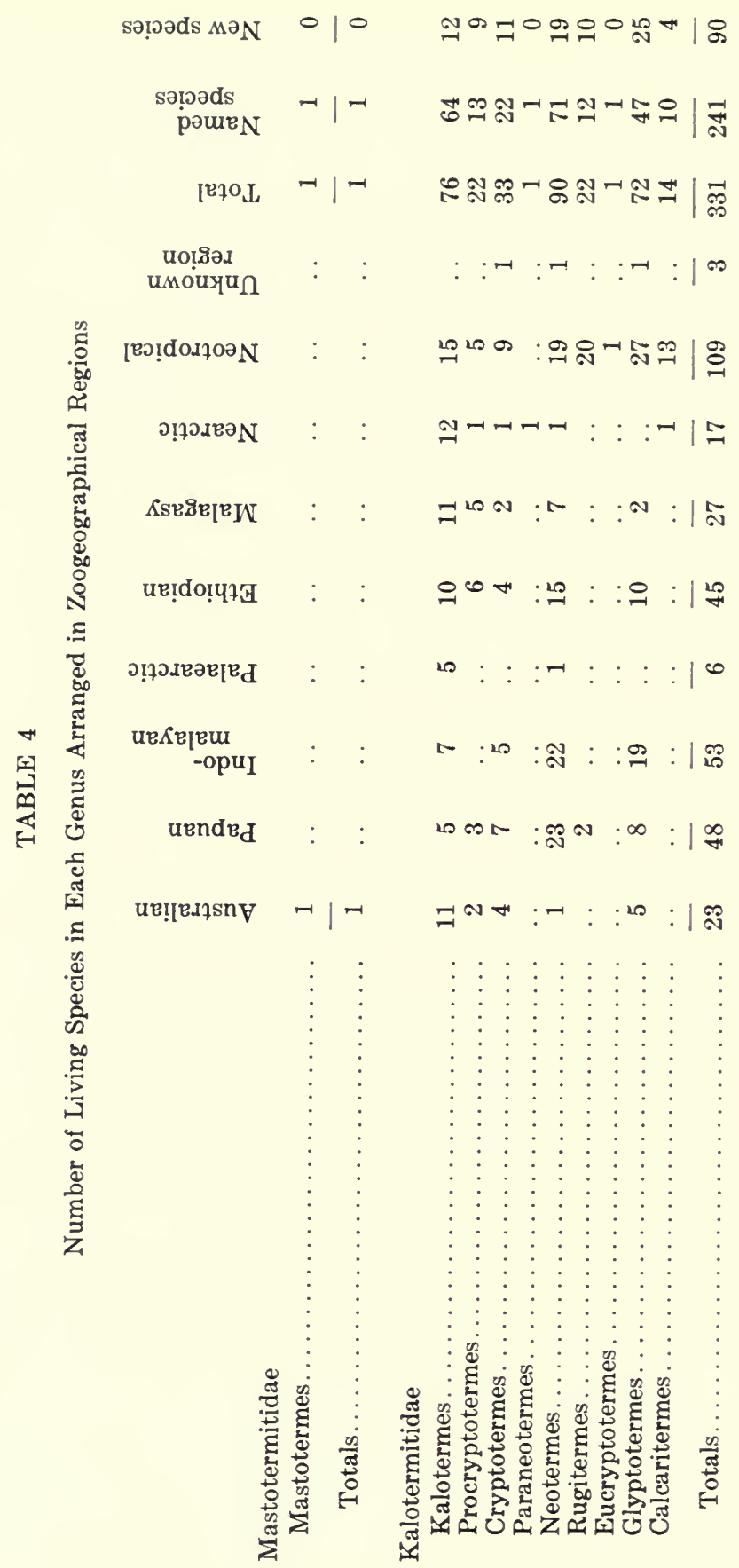




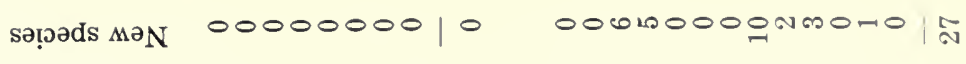

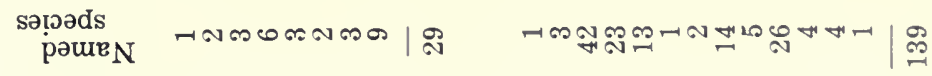

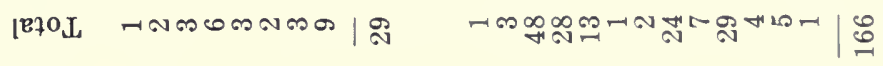

บัเรวม

uмouYun

[вว!ฺdod70әN

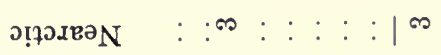

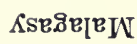

ur!̣dọ̣प7H

ว!ุวдวв[ย

ueKe[eu

-opuI

$: \infty \mid \infty$

urnded

ue!jedqsnt
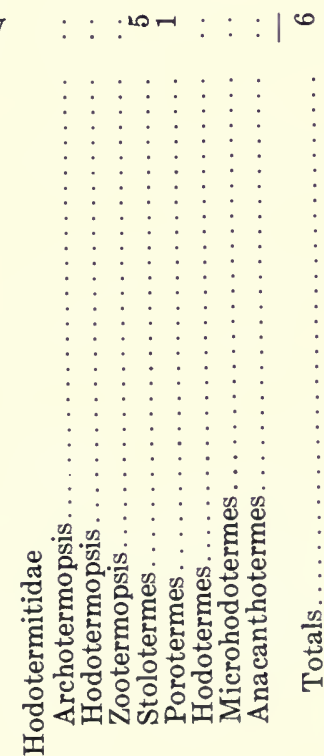

- :
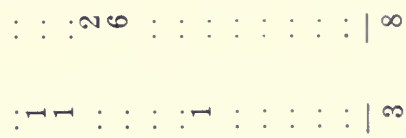

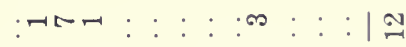

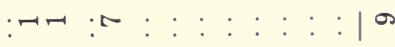

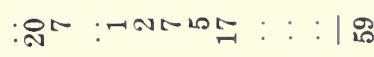

:のー: : :

.or: : : : $:$ : : 1 


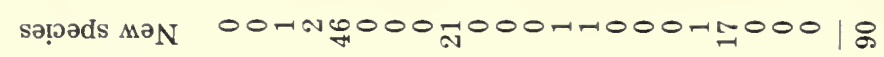

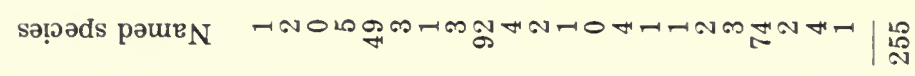

[B]OL

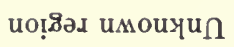
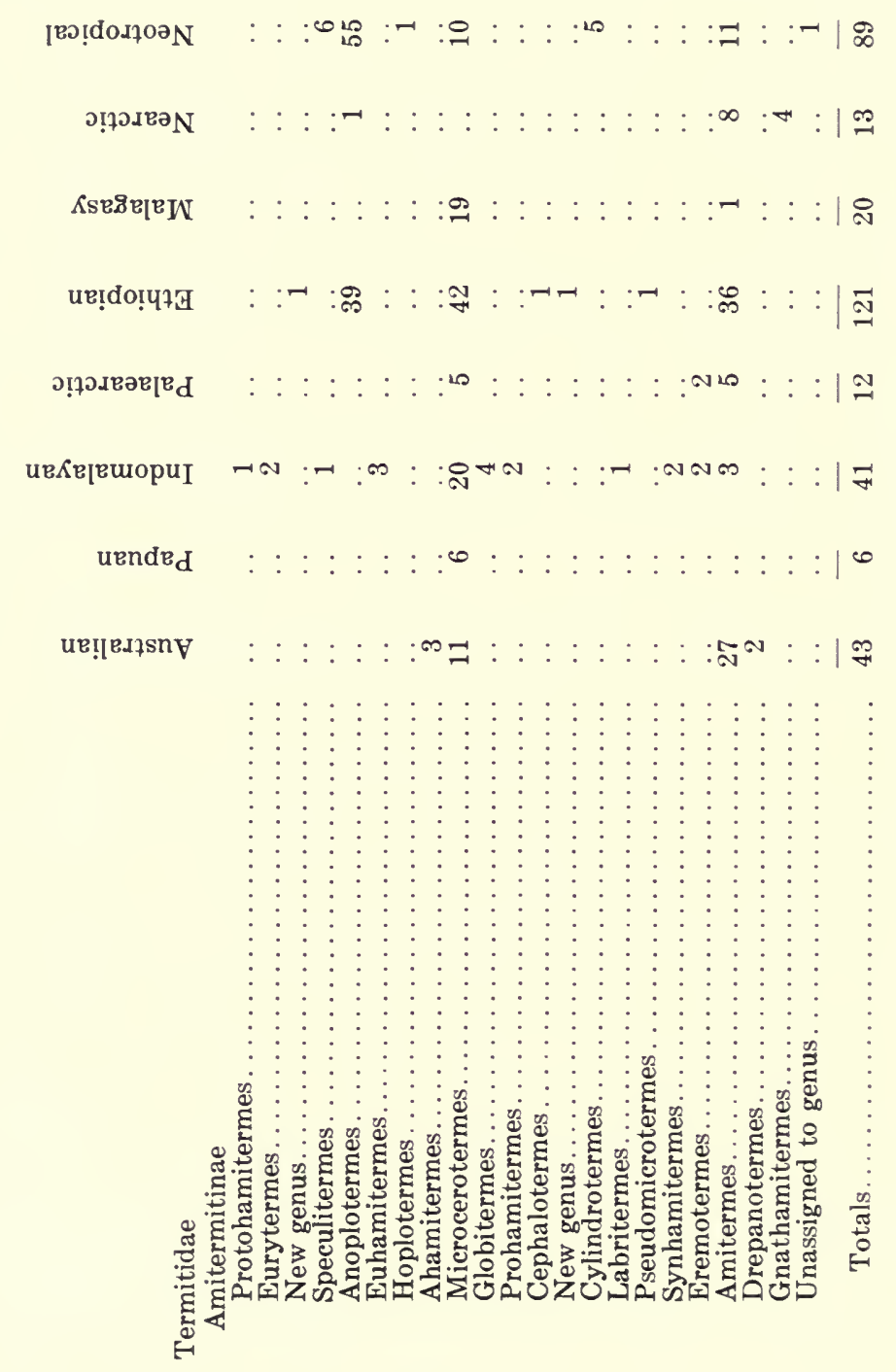


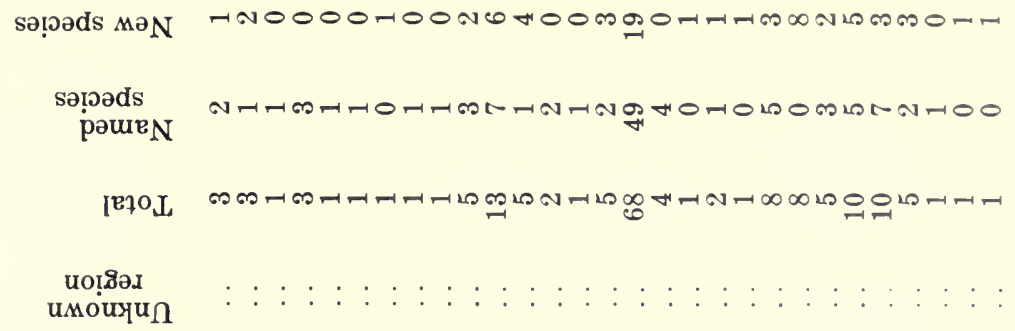

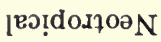

ว!ุวรอวN

Кsедере

Ue!do!̣7G

nח

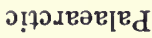

uв $\Lambda$ ери

-орuI

uended

ue!โe.Ifsn

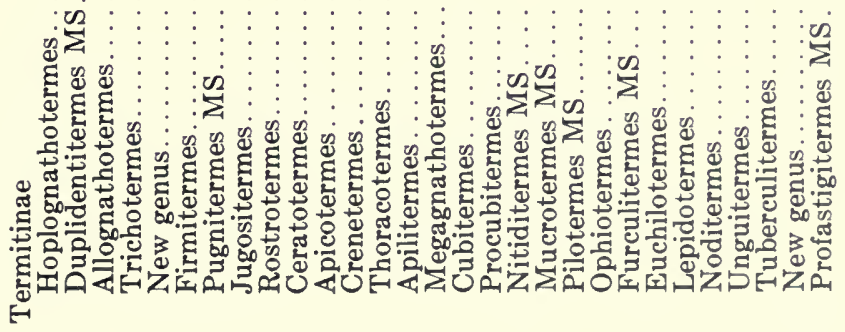




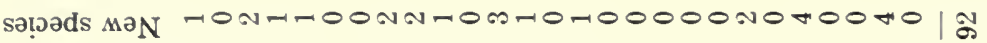

$$
\begin{aligned}
& \text { sa!jads }
\end{aligned}
$$

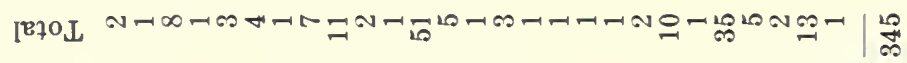

บоเฉววد

usouyun

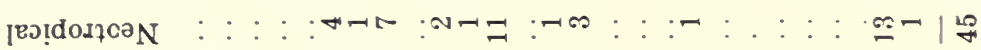
ว!ุวนอวN

Ssegeren

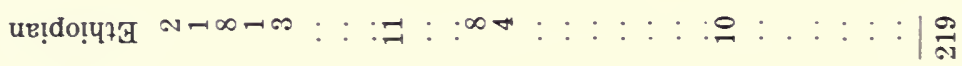

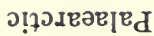

ueאe[eu

-opuI

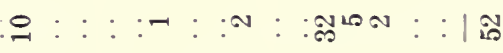

uende $\mathrm{d}$

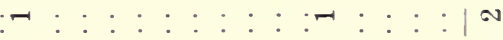

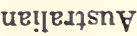

:จิ

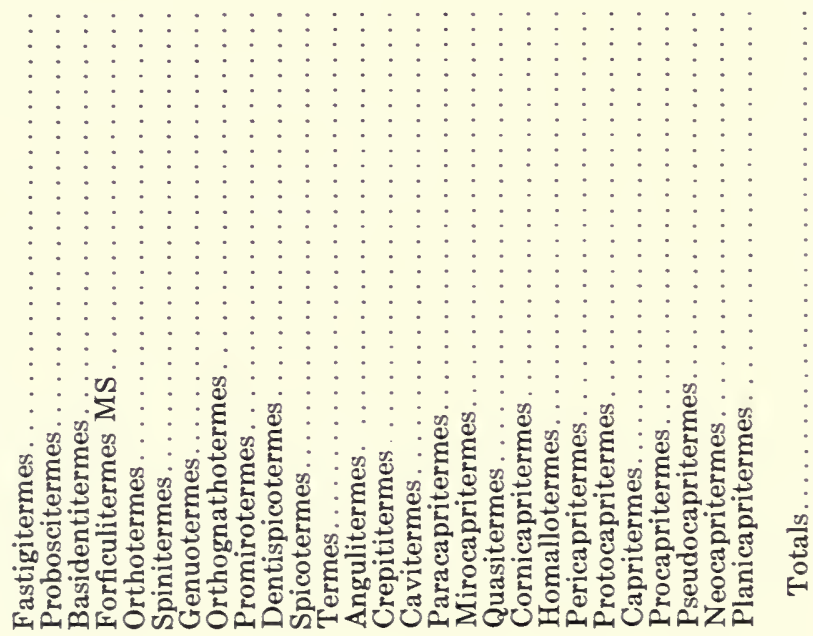



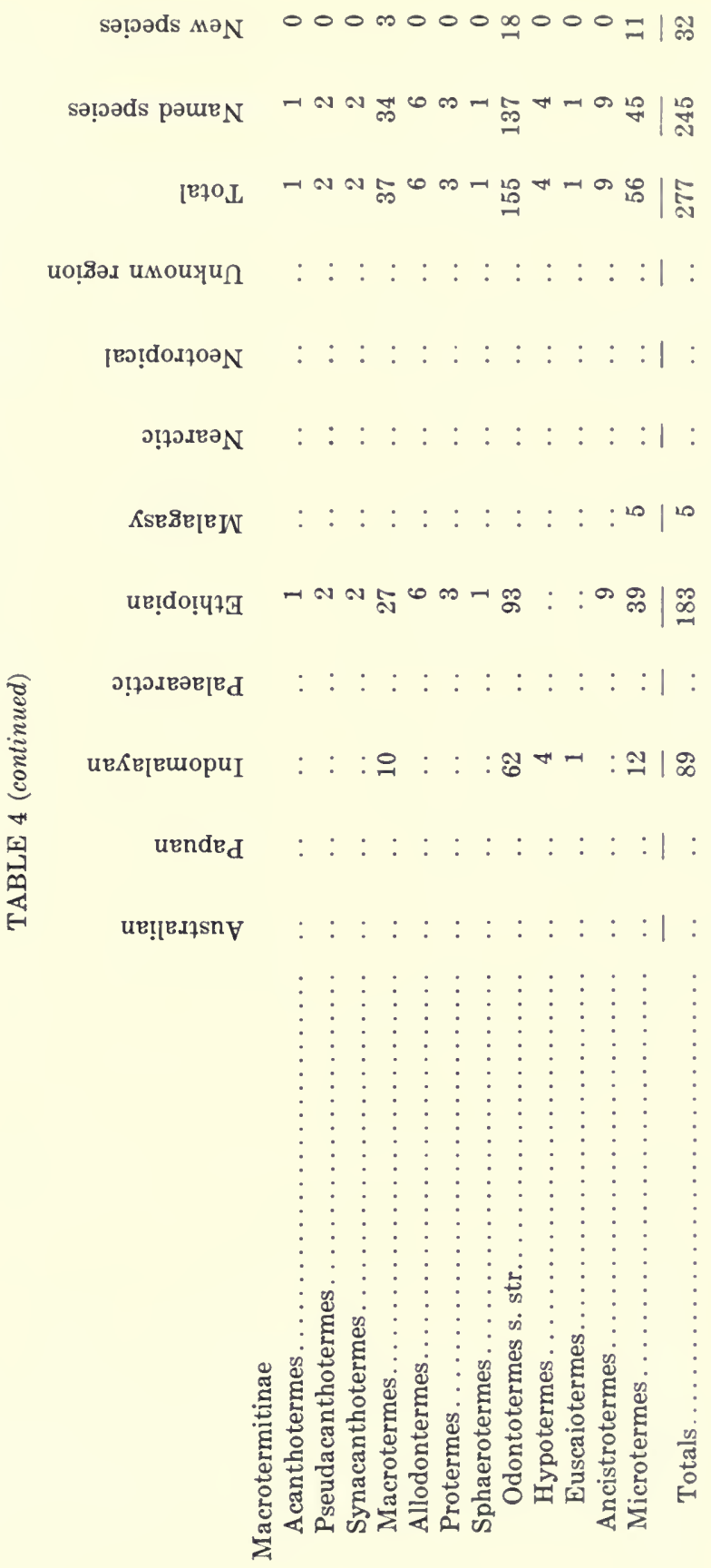


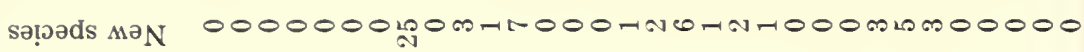

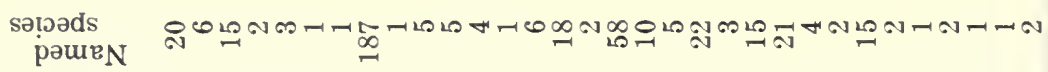

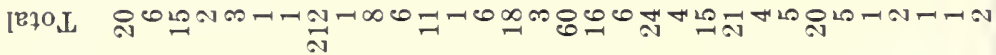
บ018ว

uмоuнu

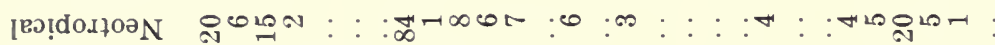

ว!ุอมอวN

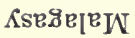

.2

uอ!̣do!บ7G

$\infty$

:

$: 0$

วุวอมรวยนе

URK E[Ru

-opuI

$\infty \pi$

$\infty: \infty \frac{\pi}{4}: \sqrt{10}$

uended

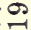

ue! [eatsn

$: \infty$

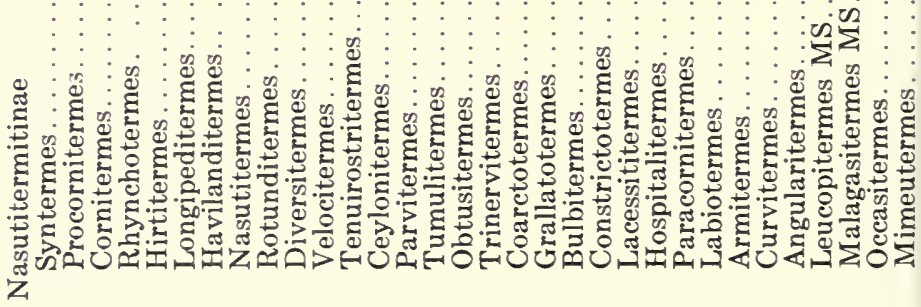




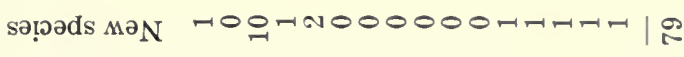

səțวads

$$
\text { [e70J }
$$

$$
\begin{aligned}
& \cos \infty \\
& \text { | }
\end{aligned}
$$

นัเรวว

uмouYun

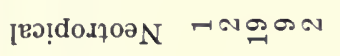

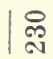

วเุวนะว

$\mid+$

ヘระภะโน

$\stackrel{\infty}{-1}$

ueเ̣do!̣tม

๖

ว!ุวนยวยโе

Ue $\Lambda$ e[eu -opuI

$m$

uende $\mathrm{d}$

ue!โยมุsn

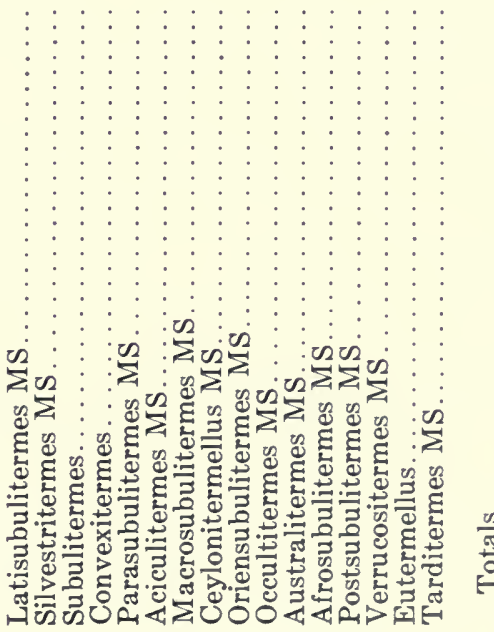

I I

i 요$$
\sqcap \mid \sqcap
$$$$
-1-
$$$$
\text { ตูต }
$$

$-1-$

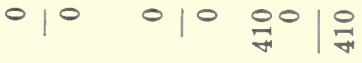

-1 $\infty \infty$

\begin{tabular}{l|l}
$\operatorname{con}^{\circ}$ & $\frac{\mathrm{N}}{\mathrm{n}}$
\end{tabular}

in

$\stackrel{10-1}{N}$

$\neg \mid-\underset{\substack{\infty \\ 0}}{\pi}$

$: 1: \stackrel{8}{*} \mid 7$

总怘 造

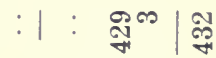

$: 1: \exists 0 \mid \Xi$

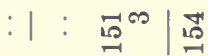

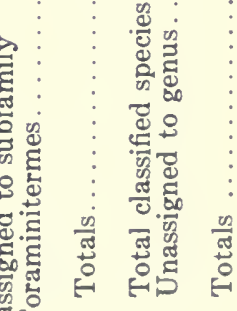




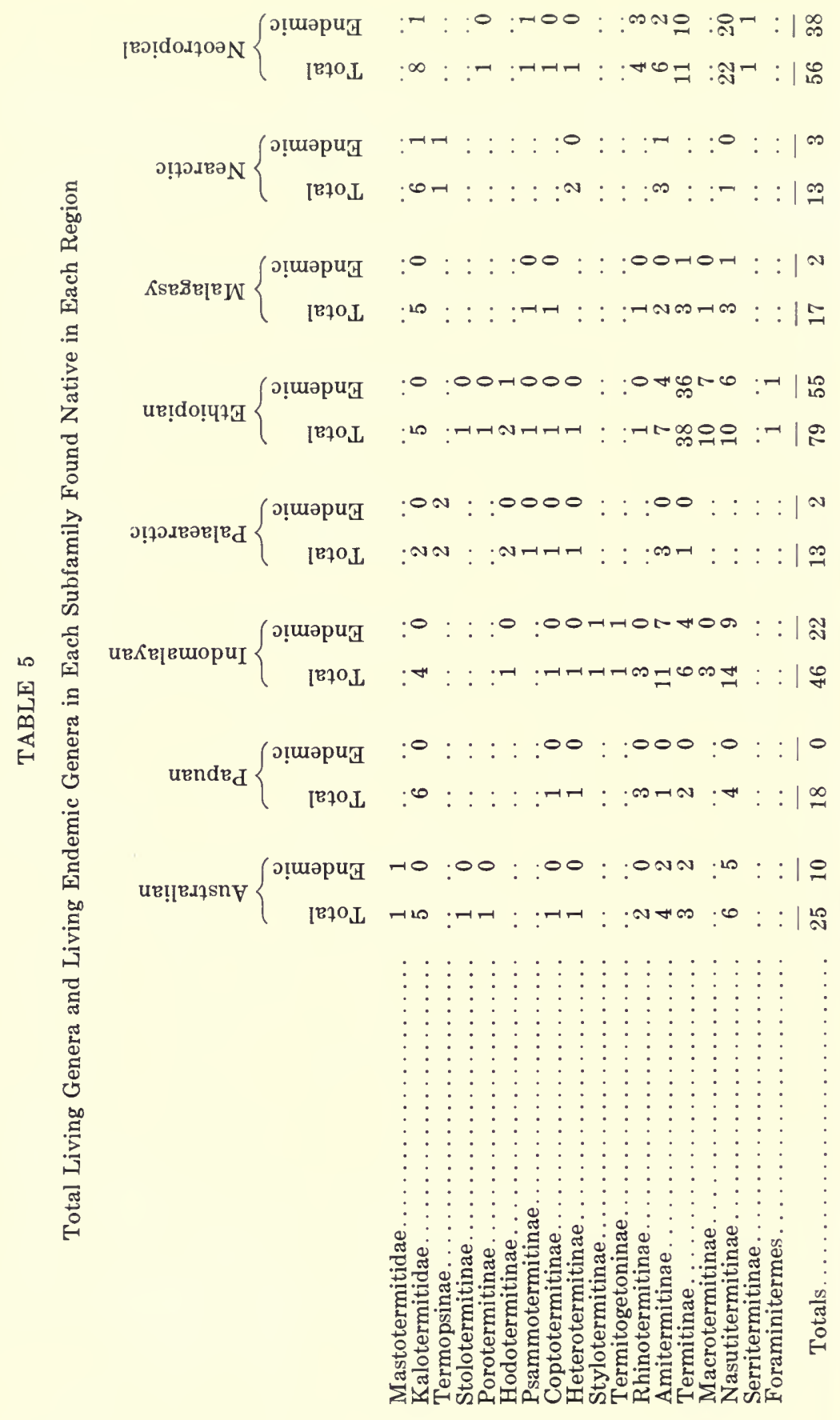




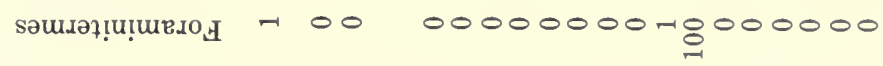

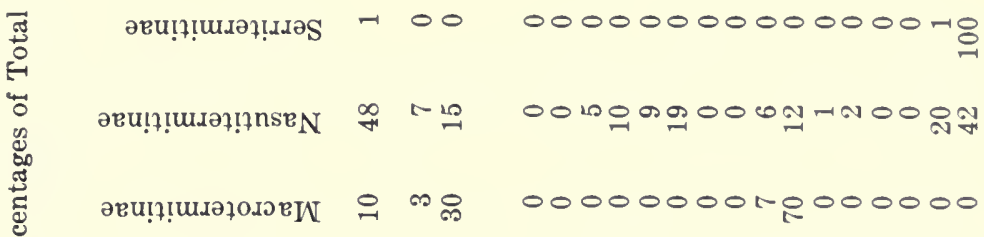$$
\text { ค. }
$$

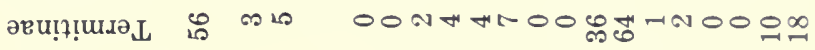

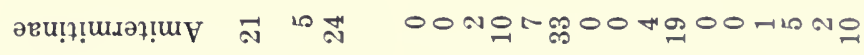

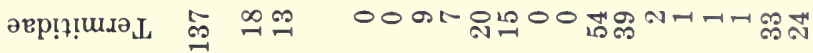

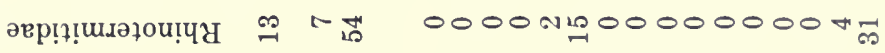

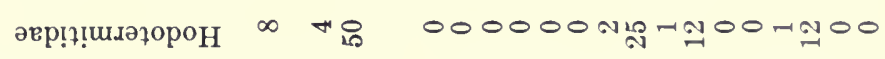

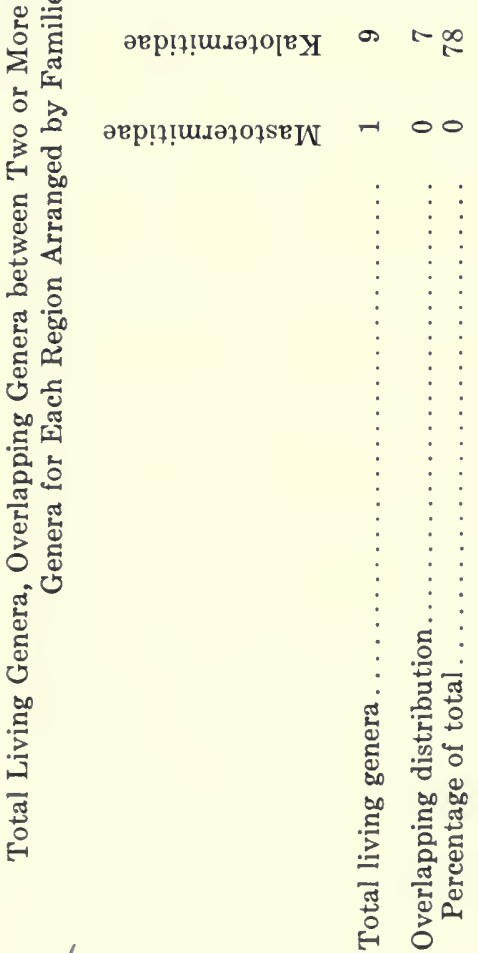

$$
\begin{aligned}
& 000000000000-H=I \\
& 00-8000000000000
\end{aligned}
$$

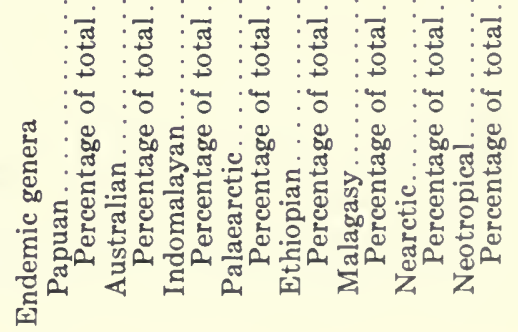




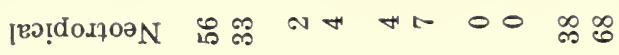

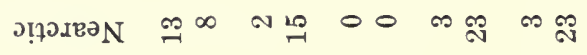

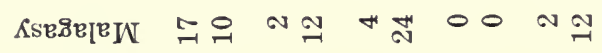

.5

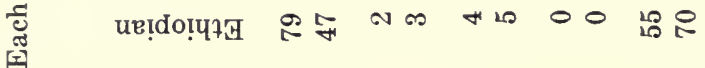

E

శ్

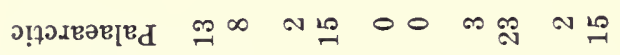

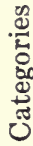

-

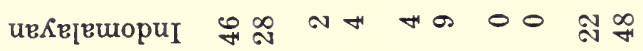

$\rightarrow$ 동

永

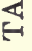

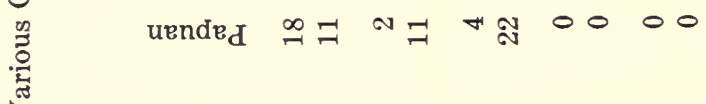

$>$

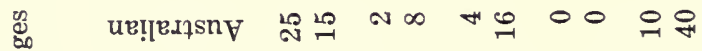



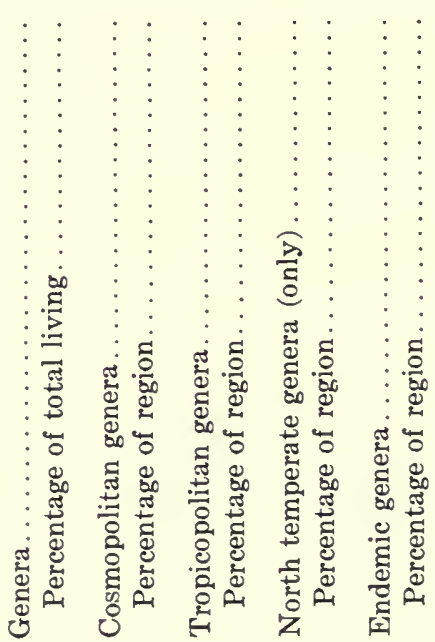




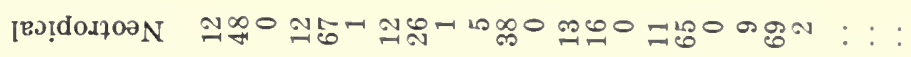

ฮี

.马

롱

वृ.

芑

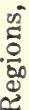

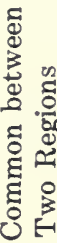

.

西

巳ั:

$\frac{2}{0}$

.Е

选

mitjiryn

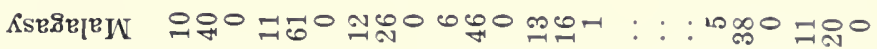

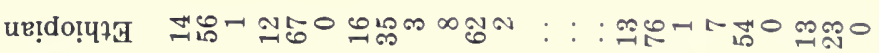

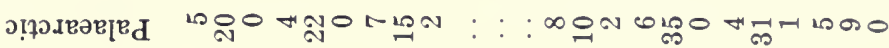

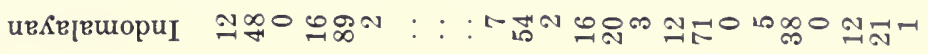

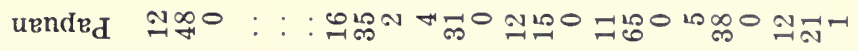

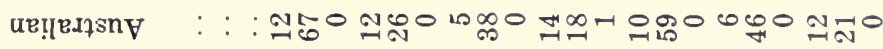

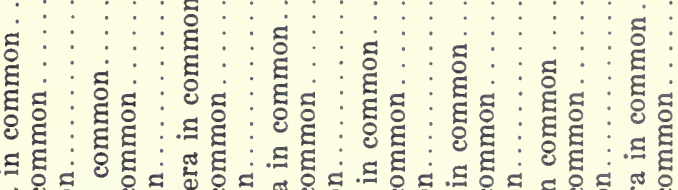
๘

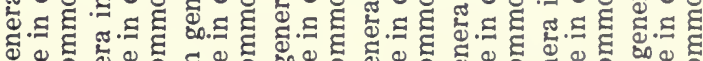
क. 焉.

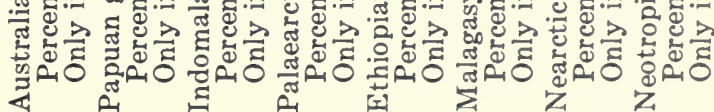




\section{REFERENCES}

\section{AhMAd, MuzafFer}

1950. The phylogeny of termite genera based on imago-worker mandibles. Bull. Amer. Mus. Nat. Hist., 95: 37-86, 17 figs.

Allee, W. C., Emerson, A. E., Park, O., Park, T., and Schmidt, K. P.

1949. Principles of animal ecology. xii +837 pp., illus. Philadelphia, W. B. Saunders Company.

Allee, W. C., and Schmidt, K. P.

1951. Ecological animal geography. xiii +715 pp., illus. New York, John Wiley and Sons, Inc.

\section{ANDER, KJELL}

1942. Die Insektenfauna des Baltischen Bernsteins nebst damit verknüpften zoogeographischen Problemen. Lunds Univ. Årsskrift (N.F. Avd. 2), 38: $1-82$.

BEAUfORT, L. F. DE

1951. Zoogeography of the land and inland waters. viii +208 pp., 10 figs. London, Sidgwick and Jackson, Ltd.

CACHAN, P.

1949. Les termites de Madagascar. Mém. Inst. Sci. Madagascar, (ser. A), $3: 177-275$.

1951. Les termites de Madagascar. Premier Suppl. Mém. Inst. Sci. Madagascar, (ser. A), 5: 1-18.

Darlington, P. J., JR.

1948. The geographical distribution of cold-blooded vertebrates. Quart. Rev. Biol., 23: 1-26, 105-123.

Emerson, Alfred E.

1925. The termites of Kartabo, Bartica District, British Guiana. Zoologica, 6: 291-459, 70 figs., 2 pls.

1928. Termites of the Belgian Congo and the Cameroon. Bull. Amer. Mus. Nat. Hist., 57: 401-574, 79 figs., 24 maps, 18 pls.

1933. A revision of the genera of fossil and recent Termopsinae (Isoptera). Univ. Calif. Publ. Ent., 6: 165-196, 40 figs.

1942. The relations of a relict South African termite (Isoptera, Hodotermitidae, Stolotermes). Amer. Mus. Nov., no. 1187, pp. 1-12, 2 figs.

1945. The neotropical genus Syntermes (Isoptera: Termitidae). Bull. Amer. Mus. Nat. Hist., 83: 427-471, 12 figs., 1 map.

1947. The imago of Stolotermes africanus Emerson. Jour. Ent. Soc. So. Africa, 9: $127-129$.

1950. Five new genera of termites from South America and Madagascar (Isoptera, Rhinotermitidae, Termitidae). Amer. Mus. Nov., no. 1444, pp. $1-15,6$ figs.

1952a. The biogeography of termites. Bull. Amer. Mus. Nat. Hist., 99: $217-225$. 
1952b. The neotropical genera Procornitermes and Cornitermes (Isoptera, Termitidae). Bull. Amer. Mus. Nat. Hist., 99: 475-540, 32 figs., 2 maps.

1953. The African genus Apicotermes (Isoptera: Termitidae). Ann. Mus. Roy. Congo Belge, (sér. 8), Sci. Zool., 17: 99-121, 4 figs.

HARE, LAURA

1937. Termite phylogeny as evidenced by soldier mandible development. Ann. Ent. Soc. Amer., 37 : 459-486, 13 pls.

HARRIS, W. V.

1954. Termites from Socotra (Isoptera). Ann. Mag. Nat. Hist., (ser. 12), 7: 493-496.

\section{Holmgren, NiLS}

1911. Termitenstudien 2. Systematik der Termiten. Die Familien Mastotermitidae, Protermitidae und Mesotermitidae. K. Svensk. Vet.-Akad. Handl., 46, no. 6, 88 pp., 6 figs., 6 pls.

1912. Termitenstudien 3. Systematik der Termiten. Die Familie Metatermitidae. K. Svensk. Vet.-Akad. Handl., 48, no. 4, 166 pp., 88 figs., 4 pls.

1914. Wissenschaftliche Ergebnisse einer Forschungsreise nach Ostindien, ausgeführt im Auftrage der Kgl. Preuss. Akad. Wissensch. Berlin von H. v., Buttel-Reepen. III. Termiten aus Sumatra, Java, Malacca und Ceylon. Gesammelt von Herrn Prof. Dr. v. Buttel-Reepen in den Jahren 1911-1912. Zool. Jahr. Abt. Syst., 36: 229-290, 1 pl.

KenNer, N. A.

1931. Die Termitenfauna von Amboina. Lunds Univ. Årsskrift (N.F. Avd. 2), 27: $1-53$.

MOREAU, R. E.

1952. Africa since the Mesozoic: with particular reference to certain biological problems. Proc. Zool. Soc. London, 121: 869-913.

Ratcliffe, F. N., Gay, F. J., and Greaves, T.

1952. Australian termites. The biology, recognition, and economic importance of the common species. $124 \mathrm{pp} ., 21$ figs. Melbourne, Commonwealth Scientific and Industrial Research Organization.

ROMER, A. S.

1945. Vertebrate paleontology (2nd ed.). viii +687 pp., illus. Chicago. Univ. Chicago Press.

1952. Discussion [of Colbert, E. H., The Mèsozoic tetrapods of South America]. Bull. Amer. Mus. Nat. Hist., 99: 250-254.

Ross, H. H.

1953. On the origin and composition of the Nearctic insect fauna. Evolution, 7: 145-158.

SeEvers, C. H.

1937. New species of termitophilous Staphylinidae from tropical America and the Solomon Islands. Ann. Ent. Soc. Amer., 30: 1-23, 20 figs., 3 pls.

Simpson, G. G.

1952. Probabilities of dispersal in geologic time. Bull. Amer. Mus. Nat. Hist., 99: 163-176.

SNYDER, T. E.

1949. Catalog of the termites (Isoptera) of the world. Smiths. Misc. Coll., Publ. 3953, 112: 1-490. 






FIEL

37-38 1955-56

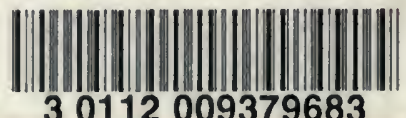

30112009379683 